doi:10.7592/TF10.retoorika

\title{
Religioossete vähemuste veebiretoorika: Rumeenia ja Ungari etnopaganlikud organisatsioonid $^{1}$
}

Rozália Klára Bakó

László Attila Hubbes

Teesid: Rumeenia ja Ungari etnotsentristlike või etnopaganlike ideoloogiatega uuspaganlike organisatsioonide sarnasuste ja erinevuste võrdlev uurimus toob välja nende religioossete vähemuste institutsionaliseerimise, põhiväärtused ja osaluse poliitikas. Zalmoxisele pühendunud rühmitused ja organisatsioonid propageerivad Rumeenia vaimsuse taasäratamist, üritades taastada sidemeid selle Daakia ja Traakia juurtega. Samamoodi on Ungari šamanistlikud liikumised suunatud väidetavalt ungari keele ja kultuuri süvakihtide kaotatud vaimsuse taastamisele. Hindamaks, kuidas need organisatsioonid kaasavad publikut, milline on nende suhtlusstiil ja multimeediavahendite kasutamine oma sõnumi edastamiseks, viiakse läbi veebiretoorika analüüs.

Märksõnad: religioossed vähemused, Rumeenia ja Ungari etnopaganad, veebiretoorika

\footnotetext{
${ }^{1}$ Bakó, Rozália Klára; Hubbes, László-Attila 2011. Religious minorities' Web rhetoric: Romanian and Hungarian ethno-pagan organizations. - Journal for the Study of Religions and Ideologies 10 (30, Winter), 127-158.
} 


\section{Sissejuhatus}

Religioon ja vaimsus on oma eksistentsi varasest staadiumist alates olnud sotsiaalse elu tähtsad dimensioonid. Traditsioonilises agraarühiskonnas on religioon üle kahe tuhande aasta olnud organiseerimispõhimõtete ja avaliku sfääri kese. Industrialiseerimine ja moodsate riikide areng on religioossete institutsioonide positsiooni muutnud, lahutades need riigist ja asetades nad 19. ja 20. sajandil privaatsfääri.

Tänapäeval ei ole globaliseerimine kaasa toonud mitte ainult religioossuse taaselustamise, vaid ka ülemaailmse vaimsete liikumiste ja organisatsioonide intensiivse loomise ja taasloomise protsessi. Infoühiskond on avaliku sfääri struktuuri ümber kujundanud ja andnud järjest rohkem ruumi privaatsetele rühmadele ja institutsioonidele, sealhulgas religioossetele organisatsioonidele. Peavoolu hulka kuuluvate ja end edukalt kehtestanud tunnustatud religioonide, nagu kristlus, islam või judaism kõrvale on 20 . sajandi viimastel aastakümnetel tekkinud arvukalt mitmekesiseid rohkem või vähem organiseeritud rühmi. Nende entiteetide, mida üldiselt määratletakse religioossete vähemustena, kuna nad moodustavad riigi rahvaarvust väikese protsendi, hääl on tänu internetirevolutsioonile 21. sajandil tugevnenud ja nad on loonud "müriaadi kübertempleid" (Campbell 2010, 31). Uuspaganlus on nähtavasti kõige kiiremini kasvav religioosne vähemus ja osa "kaasaegsest maagilisuse taassünnist" (Drury 2009, 13) nii traditsioonilises maa- kui ka linnakeskkondades (Frunză 2003, 128) ning väärib seetõttu uurimist.

Teiste tänapäeva vaimsete liikumistega võrreldes tundub uuspaganlus esmapilgul üsna ebaoluline vool isegi vähemusreligioonide seas (Rumeenias ei ole paljud tavakodanikud sellest isegi kuulnud). See võib aga tõsta küsimuse, miks peaksid arvukuselt nii ebaolulised nüüdispaganad üldse huvitama avalikkust või teadust. Ometi üritavad spetsialistid kogu maailmas leida selle erinevate väljundite tekke ja leviku põhjusi ja tingimusi. Vastused ja nende küsimuste seletused varieeruvad sama palju kui nähtus ise. Olenedes teemat uuriva autori kuuluvusest tõlgendavad mõned uuspaganlust ohuna religiooni status quo'le (Mureşan 2010, 18-19; Márton 2009), teised ohuna elutervele rahvuslikule ajaloolisele eneseteadvusele (Olteanu), kolmandad ohuna sotsiaalpoliitilisele korrale või mõnele ühiskonna elemendile (Ágoston 2008, 8), neljandad näevad uuspa- 
ganluses sonivat fantasmagooriat, mis rikub ajaloo, keele ja ideoloogia põhidiskursust (Czakó 2008), selle mõju kas üle paisutades või naeruväärsena kõrvale heites.

Rumeenia ja Ungari ideoloogialt etnotsentristlike või etnopaganlike uuspaganlike organisatsioonide võrdlev uurimus üritab kaardistada nende vähemusreligioonide sarnasusi ja erinevusi ning tuua välja nende institutsionaliseerituse taset (nende religioossuse määra), samuti nende ideoloogiate ja praktikate mõju indiviidile (vaimsuse erisused). Zalmoxisele (vahel nimetatud ka Zamolxis) pühendatud rühmitused ja organisatsioonid propageerivad Rumeenia vaimsuse taastamist, üritades taastada sidemeid selle iidsete (väidetavalt Daakia ja Traakia) juurtega. Samamoodi on Ungari šamanistlike liikumiste eesmärk taastada ungari keele ja kultuuri eeldatav kaotatud vaimsus.

Kahel põhjusel otsustasid autorid sooritada uurimuse tähelepandamatult, kogudes andmeid ainult WWW avalikult postitatud allikatest. Esimene põhjus on aktuaalsus: uurimus keskendub Rumeenia ja Ungari etnopaganlike organisatsioonide poolt laiemale avalikkusele suunatud internetipõhistele sõnumitele. Teiseks keskendub analüüs metodoloogilistel põhjustel esitluse retoorikale (presentational rhetoric, Van Maanen, Schein 1977, 21), sest vahetule retoorikale (operational rhetoric) ehk vähemusreligioossete organisatsioonide igapäevasuhtlusele ligipääsemiseks tuleb täiesti integreeruda ja sotsialiseeruda rühmaga, osaleda nende rituaalides ja tegeluses - olla siseringi liige. Samas ei saa me veebipõhiseid organisatoorseid diskursusi uurides ignoreerida neis osalejate veebivälist konteksti ja seotust kindlate sotsiaalsete reaalsustega, vastasel korral me riskime "ääreala nägemusega" neist nähtustest (Fairclough 2005, 915).

Meie käsitluse uurimisküsimused on:

I Millised on Zalmoxisele pühendatud ning šamanistlike rühmituste veebiretoorika sarnasused ja erinevused?

II Millised on Zalmoxisele pühendatud ja šamanistlike rühmituste seosed poliitiliste ja sotsiaalsete liikumiste ning organisatsioonidega?

III Milline on nende rühmituste ja liikumiste institutsionaliseerituse tase? Kas nad tegutsevad registreeritud organisatsioonidena või on pigem mitteametlikud rühmitused?

IV Kui suures ulatuses määratlevad need rühmitused end religioossena? Kui suures osas etnopoliitilisena? 


\subsection{Kontseptuaalne raamistik}

Vastandina ajaloolistele iidsete kultuuride paganlusele tähendab uuspaganlus katusterminit, mille alla koonduvad tänapäevased autoriteedivastased loodusorientatsiooniga linlikud protestireligioonid, mis said alguse nii Euroopa müstitsismist kui ka 18. ja 19. sajandi romantismist. Lähteainest on ammutatud iidsetest klassikalistest usurühmitustest, eelkristlikest religioonidest ja Euroopaväliste hõimude uskumustest. Need üldiselt polüteistlikud või tinglikult monoteistlikud usundid eelistavad isiklikke rituaalikogemusi ja neil on mõningaid olulisi sarnasusi, nagu näiteks taasmütologiseerimine, ökologism ja naisprintsiibi tunnustamine (Grieve 1995, 88; Kis-Halas 2005, 56-57; Szilárdi 2007, 72).

Uuspaganlike liikumiste haare on üsna lai, ulatudes ühes äärmuses ekletitilistest kuni sünkreetiliste brikolaažkultusteni (nagu näiteks wicca, neodruidism, (linna)šamanism) ja teises äärmuses olevate kultuurispetsiifiliste traditsioonideni, nagu näiteks monoteistliku või polüteistliku rekonstruktsionismi mitmed variandid (vt Adler 1979, 436-437). Käesoleva uurimuse seisukohalt pakub huvi just rekonstruktsionistlik paganlus, mis üritab väga hoolikalt uuesti üles ehitada teatud usutraditsiooni minevikku, kasutades selleks "üsna oskuslikult teaduslikke uurimusi iidsete tekstide, rahvaluule, arheoloogia ning keelte kohta", mida usutakse sisaldavat väga usaldusväärset informatsiooni taaselustatava usu kohta (Strmiska 2005, 19). Samal ajal välistatakse rangelt eklektilised tavad ja ideed, et säilitada iidse religiooni puhtus. Rekonstruktsionistid tunnevad siiski vajadust kohandada vanad rituaalid vastavaks tänapäeva oludele ja tunnustada individuaalset vaimset inspiratsiooni.

Meie analüüsitavat keerulist nähtust - Ungari ja Rumeenia uuspaganlikud organisatsioonid ja nende internetiretoorika - võib kirjeldada nii religioosse kui ka vaimsena. Viiteraamistiku määratlemiseks kasutame Lundskow' lähenemist, mis vastab duaalsele uuspaganate individualistlikule ja kogukondlikule maailmavaatele (Lundskow 2008, 4). 
Tabel 1. Erinevus religioossuse ja vaimsuse vahel.

\begin{tabular}{|l|l|}
\hline Religioon & Vaimsus \\
\hline $\begin{array}{l}\text { Ühise heaolu eetika: kogukonna } \\
\text { vajadused on olulisemad kui } \\
\text { vähemuse või üksikisiku omad }\end{array}$ & $\begin{array}{l}\text { Individuaalne eetika: } \\
\text { uskumused ja väärtused } \\
\text { teenivad indiviidi heaolu }\end{array}$ \\
\hline $\begin{array}{l}\text { Ühise heaolu moraalsus: } \\
\text { institutsioon määrab õige ja } \\
\text { vale }\end{array}$ & $\begin{array}{l}\text { Individuaalne moraalsus: } \\
\text { indiviid otsustab, mis on õige, } \\
\text { mis vale }\end{array}$ \\
\hline $\begin{array}{l}\text { Institutsionaalne autonoomsus: } \\
\text { religioon eksisteerib } \\
\text { põlvkondade-vaheliselt ega } \\
\text { sõltu isiklikust kontrollist }\end{array}$ & $\begin{array}{l}\text { Isiklik autonoomsus: vaimsus } \\
\text { eksisteerib iga indiviidi } \\
\text { sisemuses eraldi }\end{array}$ \\
\hline $\begin{array}{l}\text { Institutsionaalne hegemoonia: } \\
\text { eksisteerib indiviidi-väliselt, } \\
\text { on sunduslik; reageerib } \\
\text { ajaloolistele muutustele, ei } \\
\text { sõltu isiklikest otsustest }\end{array}$ & $\begin{array}{l}\text { Isiklik hegemoonia: isiklik } \\
\text { valikuvabadus, isiklikele } \\
\text { tunnetele ja valikutele } \\
\text { reageerimine }\end{array}$ \\
\hline
\end{tabular}

Allikas: Lundskow 2008: 4.

Ükskõik, kas rekonstruktsionismi mõistetakse religioossuse või vaimsusena, viitab see nii harrastajate kui ka teadlaste kasutuses pigem iidsetele klassikalistele religioonidele nagu egiptuse, kreeka, romaani, keldi või skandinaavia polüteismile. Teisest küljest ei kata see täielikult tänapäevaste riikide religioonide taaselustamisliikumisi. Viimased sarnanevad vormilt küll rekonstruktsionismile, kuid tegelevad pigem kaasaegses riigis eksisteerinud vanade, eelkristlike ja eelislamistlike paganlike kultustega, kusjuures rõhku pannakse rahvusele.

Nende liikumiste kohta võib kasutada ka terminit "etnoreligioon", eeldades, et seda mõistet ei kasutata etnosepõhiste klassikalisemate denominatsioonide kohta. See viitab kas religiooni põhisuundade (roomakatoliku, õigeusu) etnilistele kirikutele või nüüdisaegsetele 
põlisrahvaste traditsioonilistele religioonidele (Aasia, Aafrika, Vaikse ookeani piirkonna, Ameerika põlisrahvaste animistlikud, totemistlikud, šamanistlikud, teistlikud usundid), mis katkematult tänapäevani säilimise tõttu rekonstrueerimist ega taaselustamist ei vaja. Täpse termini puudumisel tuleb rekonstruktsionistliku paganluse ja etnilisuse mõisted liita eriliseks etnopaganluse mõisteks. See termin ühendab arvukad Euroopale (eriti Ida-Euroopale) omased uuspaganlikud liikumised. Näited on allpool täpsemalt välja toodud, hetkel viitame ainult põgusalt erinevatele slaavi, balti või meie põhilisele uurimiseesmärgile, ungari ja rumeenia etnilistele uuspaganate rühmadele.

Paganlusega ühendatud etnilisus tähendab rõhutatud etnotsentrismi või isegi etnilise ülimuslikkuse või esmasuse ideid, mis leivad tihti väljundi natsionalistlikes poliitilistes liikumistes. Schnirelman täheldas postsovetliku aja ja alade kohta, et uuspaganluse kiire kasv on tihedalt seotud etnilise natsionalismi kasvuga, kusjuures natsionalistlike liikumiste aktivistid kutsusid üles (etnilise, eelkristliku) rahvusreligiooni taastamisele (Schnirelman 2002, 198). Sama on toimunud ka enamikus Kesk- ja Ida-Euroopa riikides või isegi terves maailmajaos.

Pöörame Rumeenia ja Ungari etnopaganate rühmitusi vaadeldes tähelepanu eelkõige nende poolt deklareeritud ülesannetele ja väärtustele, organiseerituse tasemele, võimalikele sidemetele poliitikaga ning mõjule isiksuse tasemel. Arvestades asjaolu, et nooremad põlvkonnad on palju rohkem "kaabeldatud" küberruumi ja internetiga kui täiskasvanud või vanemad põlvkonnad, nad on tihti poliitilise radikaliseerimise sihtrühm (Ágoston 2009, 45). Etnotsentriliste diskursuste kiirel levikul internetis võib olla märkimisväärne poliitiline mõju, ning seetõttu on mõttekas seda uurida. Noore inimese puhul on tõenäolisem, et temast võib saada "tehnopagan", või "dünaamiline, mitmenäoline ja kiiresti kohanev tegija, kes suudab edukalt esitada väljakutse traditsioonilisele humanistlikule binaarsusele looduse ja tehnika, teaduse ja religiooni, inimliku ja mitteinimliku vahel" (Gallacher 2008, 3). Samal ajal on religioossed liikumised võimekamad mobiliseerima noori inimesi nii demokraatlikes kui ka mittedemokraatlikes suundades (Radu 2010, 161).

Kuna etnopaganlus levib infotehnoloogiaga tihedalt ühenduses olevate nooremate põlvkondade seas, peaksime meeles pidama 
seda, mida Dino Cardone kutsub internetiretoorika õõnestavuseks. Internet on vanema elektroonilise meediaga võrreldes üsna vähe kontrollitud ning selle tõttu aldis ebatavalistele ja äärmuslikele diskursustele, kus individuaalne reetor võib suhelda vabana traditsiooniliste institutsionaalse teaduse, teoloogia või muude kaanonite surveta (Cardone 2007, 5). Sotsiaalmeedia aga, kus ühelt poolt domineerib noorem põlvkond ning mis on teiselt poolt triiki täis omavahel võistlevaid mittekanoonilisi religioosseid või poliitilisi ideid, pakub etnopaganate rühmitustele suurepärase kasvulava nii oma ideede vaevata levitamiseks kui ka organiseerumiseks. Käesoleva uurimuse seisukohalt tuleb tõdeda, et "kuigi paljud religioossed rühmad kasutavad internetti, suudab vaid uuspaganlus kujundada kogukonda [---] küberruumis" (Grieve 1995, 103).

\section{Uurimuse taust}

Uuspaganlus on üks kiiremini kasvavatest vaimsetest liikumistest ja samal ajal vääritimõistetumatest religioonidest. Terminit uuspaganlus kasutavad teadlased rohkem kui selle harrastajad (Lundskow 2008, 30), mistõttu peaks, arvestades selle alla kuuluvate ideoloogiate ja kultuste suurt varieeruvust, käsitlema seda katusterminina. Üks suurimaid vääritimõistmisi seoses uuspaganatega on see, et neid peetakse satanistideks ja kurjuse kehastuseks ning neile omistatakse igasugune kuritegevus alates uimastite tarbimisest, vägistamistest ja lõpetades rituaalse inimohverdusega. Hoolimata sellest, et politsei ei ole kunagi registreerinud ühtegi rituaalse vägistamise või mõrva juhtumit, on eelarvamus tugev (Lundskow 2008, 308-309). Uuspaganluse halba mainet toetavad peamiselt traditsioonilised põhikonfessioonid, etnopaganate puhul on aga pilt veelgi mustem, sest avalikkuses ja teaduslikus käsitluses peetakse neid neonatsideks nende väidetava või ka tegeliku seose tõttu selliste ideoloogiatega (Borangic 2008; Schnirelman 2002; Lupu 2007).

\subsection{Rahvusvaheline uuspaganluse uurimine}

Ameerika Ühendriikides (liikumise kõige enam dokumenteeritud ala) läbi viidud uurimuse kohaselt on uuspaganad pigem valged, noored ja haritud (Berger et al. 2003, 27-32). 
Tabel 2. Uuspaganate keskmine vanus USAs.

\begin{tabular}{|l|l|l|l|l|l|l|l|l|l|}
\hline Vanus & $8-9$ & $10-19$ & $20-29$ & $30-39$ & $40-49$ & $50-59$ & $60-69$ & $70-79$ & $\begin{array}{l}\text { Ei } \\
\text { vasta- } \\
\text { nud }\end{array}$ \\
\hline$\%$ & 0.1 & 3.6 & 29.1 & 34.3 & 24.5 & 7.9 & 2.1 & 0.2 & 2.7 \\
\hline
\end{tabular}

Allikas: Berger et al. 2003, 27.

Tabel 3. Uuspaganate rass USAs.

\begin{tabular}{|l|l|l|l|l|l|l|l|}
\hline Rass & Valge & Must & Aasia & $\begin{array}{l}\text { Põlis- } \\
\text { ameerik- } \\
\text { lased }\end{array}$ & Latiino & Muud & $\begin{array}{l}\text { Ei } \\
\text { vastanud }\end{array}$ \\
\hline$\%$ & 90.8 & 0.2 & 0.2 & 0.9 & 0.7 & 2.4 & 0.2 \\
\hline
\end{tabular}

Allikas: Berger et al. 2003, 30.

Tabel 4. Uuspaganate haridustase USAs.

\begin{tabular}{|l|l|l|l|l|l|l|l|l|l|}
\hline $\begin{array}{l}\text { Hari- } \\
\text { dus }\end{array}$ & $\begin{array}{l}\text { Kesk- } \\
\text { koolis } \\
\text { mitte- } \\
\text { käi- } \\
\text { nud }\end{array}$ & $\begin{array}{l}\text { Kesk- } \\
\text { kool }\end{array}$ & $\begin{array}{l}\text { Osa- } \\
\text { line } \\
\text { kol- } \\
\text { ledž }\end{array}$ & $\begin{array}{l}\text { Kol- } \\
\text { ledž }\end{array}$ & $\begin{array}{l}\text { Tehni- } \\
\text { line } \\
\text { hari- } \\
\text { dus }\end{array}$ & $\begin{array}{l}\text { Töö } \\
\text { oman- } \\
\text { datud } \\
\text { erialal }\end{array}$ & $\begin{array}{l}\text { Kraadi- } \\
\text { oppur }\end{array}$ & $\begin{array}{l}\text { Muu } \\
\text { vasta- } \\
\text { nud }\end{array}$ \\
\hline$\%$ & 2.4 & 5.4 & 25.4 & 25.5 & 11.6 & 11.4 & 15.9 & 1.6 & 0.6 \\
\hline
\end{tabular}

Allikas: Berger et al. 2003, 32. 
Kuna uuspaganad kalduvad tegutsema avalikkuse eest varjatult, on võimatu uurida neid juhuvaliku põhimõttel. Et aga rühmad on internetis väga aktiivsed ja omapäi harrastajate arv kasvamas (Berger 2010), võimaldab "võrgustatud individualism" (Coco 2011) sooritada väga suure vastajate arvuga uurimusi internetis. Helen Berger ja tema uurimisrühm tegid esimese uurimuse uuspaganlusest 2003. aastal USAs. Kasutades veebipõhiseid küsimustikke laiendas ta selle 2007. aastal rahvusvaheliseks küsitluseks, millele vastas ligi 8000 inimest (Berger 2010). Mõlema küsitluse tulemused olid sarnased, põhiline erinevus 2003. ja 2007. aasta tulemustes oli üksikharrastajate arvu oluline suurenemine: omaette tegutsejate hulk oli suurenenud 51\%-lt 79\%-ni. Üksikharrastajate arvu kasvu on toetanud raamatud ja internet. Religiooni esialgse levimise ajal 1960. ja 1970. aastatel anti seda edasi enamasti inimeselt inimesele rühmades, nt kodades (coven) (Berger 2010).

Et me ei tea süvauuringuid ega statistilisi analüüse, mis pakuksid Rumeenia ja Ungari uuspaganate kohta arvandmeid, ameteid, vanust, sugu, rassi või orientatsiooni, ei saa me vastavaid tulemusi esitada. ${ }^{2}$ Kuigi Ungaris on registreerimata ja registreeritud kirikuid 150 ja 200 vahel, on neist enamus väiksemad kogudused ja religioonid. ${ }^{3}$ Réka Szilárdi viitab statistilistele andmetele (Török 2004, 34), mille kohaselt uusreligioossete liikumiste pooldajad ei ületa ühte protsenti Ungari rahvastikust, kusjuures uuspaganaid on nende hulgas ülivähe (Szilárdi 2007, 71). Samal ajal tunnustab Rumeenia ainult 18 kultust ja usulahku, millest ükski ei ole uuspaganlik (usuvabaduse ja usulahkude kohta käiva seaduse nr 489/2006 kohaselt) ning vähem kui 3 protsenti rahvastikust tunnistas 2002. aasta rah-

${ }^{2}$ Margareta Lupu räägib Gebeleizise ühingu 15 harust, millel on kokku 500 liiget (Lupu 2007). Mõnede ungari etnopaganlike koguduste aktiivsete toetajate arv ulatub ainult paari tuhandeni: Ósmagyar Egyház (Ülem-Ungari kirik) 965 liiget, Kelta Wicca Hagyományórzók Egyháza (Keldi traditsiooniline Wicca kirik) 431 liiget, Árpád Rendjének Jogalapja Tradicionális Egyház (Ground Arpad'i ordu traditsiooniline kirik) 307 liiget, Nagyboldogasszony Szeretet Egyház (Jumalaema armastuse kirik) 211 liiget, Magyar Vallás Közössége (Ungari usukommuun) 55 liiget, Ósmagyar Táltos Egyház (Ülem-Ungari Taltose kirik) 0 (!) liiget; andmed põhinevad annetajatel, kes on andnud 1\% oma tuludest mittetulundusühingutele. (Szốnyi Szilárd.)

${ }^{3}$ Vastavalt 2010. aasta 1 . märtsi seisuga esitatud koondnimekirjadele, mis põhinevad erinevatel statistikatel, mis on avaldatud http://www.apologia. hu/pdf/churchlist-type.pdf ja http://www.apologia.hu/pdf/churchlist-abc.pdf (nimetatud on ainult kuus uuspaganlikku kirikut). 
valoendusel enda usuks "muu religiooni" (INS 2004, 9), 2011. aasta rahvaloenduseks oli nende hulk veelgi kahanenud: neid oli jäänud alla 2 protsendi (INS 2010). Sellistes tingimustes on raske pakkuda mingit võrdlust, kuid siiski on teatud üldtendentsid, mis ilmselt kehtivad nii Ungari kui ka Rumeenia etniliste uuspaganate kohta.

Üldjoonte äratundmiseks on vajalik ülevaade uuspaganluse teoreetilistest käsitlustest nii rahvusvahelisel kui ka piirkondlikul tasemel. Kuna uuspaganlus on hästi uuritud ja põhjalikult kirjeldatud nähtus, piirdume siinkohal paari hädavajaliku põhiideega.

Réka Szilárdi väidab: "Uuspaganlikud kogukonnad reageerivad postmodernistlikele oludele vastanduva suhtumisega, proovides luua võimalikult laiaulatuslikku ja universaalselt paikapidavat enesemääratlust, üritades sulandada usaldusväärseks tervikuks keelelisi, etnilisi, religioosseid ja isegi poliitilisi identiteete. [...] Mõnes mõttes käituvad need liikumised kui rahvuse alusel organiseeritud etnilised kogukonnad. See aga ei tähenda, nagu hindaks neid selle põhimõtte järgi ühiskonna enamus, vastupidi, tihti reageerivad need liikumised vähemusrühmana oma keskkonnale, millest nad etnilises võtmes ei pruugi üldse erinedagi" (Szilárdi 2007, 71). Ta lisab, et nende kogukondade loomine on samaaegselt nii reaktsioon sekulariseerumisele kui ka traditsioonilistest religioonivormidest eemaldumine (Szilárdi 2007, 71-74).

Sarah Pike rõhutab, et uuspaganlus kui loodusele suunatud religioossus on osaliselt sündinud vajadusest kogukonna järele: "vaimne vägi ja kogukonnale pühendumine puudub enamikust protestandi ja katoliku kirikutest", ning lisaks ka murest inim- ja looduskeskkonna pärast: "uuspaganad on pühendunud nende religioossete valikute järgimisele, mis nende arvates tagavad inimeste ja looduse tasakaalu, sakraliseerivad keha ja seksuaalsust, ravivad sallimatuse põhjustatud haavu ning loovad eluterved ja rahuarmastavad kogukonnad" (Pike 2001, xiii). Samal ajal on väga laialt levinud välise religioosse autoriteedi eitamine isiklike vaimsete vajaduste kasuks (Pike 2001, xx).

Meie piirkonna relevantsematest uurimustest rääkides tuleb kõigepealt mainida Adrian Ivakhivit (Ivakhiv 2005, 194-196), kes näitab, et Euroopa ning eriti Ida-Euroopa uuspaganlikes liikumistes on loodus ja etnilisus seotud tihedamalt kui lääne usundi-uurijad tavaliselt eeldavad.

Sedasorti inimese ja looduse kontiinum, mida propageerivad tänapäeva Ida-Euroopa paganad, võib esmapilgul paista kiiduväärt 
ökoloogilise pü̈̈llusena suunata inimesi tagasi looduskeskkonda, mis sarnaneb populaarse Põhja-Ameerika keskkonnateadlikkusega. See tõstatab aga etnilise valivuse okkalise küsimuse - kes kuulub ja kes mitte. See on küsimus, mis on kimbutanud etnilisi suhteid peaaegu igas maailmanurgas ja mis kuulub poliitiliselt pigem paremale kui vasakule. [---] Loodust määratlevad paljud Ida-Euroopa paganad kui territoriaalset etnilisust. See on põhikomponentidelt põhja-ameeriklastest ja lääne-eurooplastest palju avaram looduse käsitlemine (Ivakhiv 2005, 196).

Ka Victor Schnirelman rõhutab uuspaganluse ja natsionalismi tugevaid sidemeid: "paganluse poole pöördumine tähendab etnilisrahvaliku kultuse rajamist, teatud sorti 'rahvuslikku vaimu', et ühendada rahvast tema vabaduspüüdlustes" (Schnirelman 2002, 205). Tema vaatepunktist toetuvad Ida-Euroopa uuspaganad tugevalt etnotsentristlikule diskursusele, kus paganlus tähendab naasmist esivanemate puhta ja rikkumata eelkristliku kõlbluse juurde, kristluses nähakse tihti rõhujat või kurja välismaist sissetungijat. "Uuspaganaid lummab sügavalt eelkristlik minevik, justkui oleksid inimesed elanud sel ajal täiuslikus puhtuses ja olnud rikkumata välismõjudest ning suutelised selle tõttu nautima maailma parimat ideoloogiat, pidama edukalt sõdu ja tegema imelisi vägitegusid" (Schnirelman 2002, 204). Anne Ferlat on analüüsinud new age'i ja uuspaganlikke liikumisi tänapäeva Venemaal, koondades nad termini uusreligioosne laine alla ning viidates mõlema etnilisele ja kristlusevastasele iseloomule (Ferlat 2003, 40-49).

Ungari ja Rumeeniaga seoses on olulised ungarlase Tamás Szilágyi seisukohad, kes eristab põhimõtteliselt new age liikumise ja uuspaganluse:

...leiame nende kahe liikumise juures nii palju hajusaid ideid, mis muudavad võimatuks nimetada uuspaganlust osaks new age'i liikumisest. Need on ilmselgelt eraldiseisvad religioossed nähtused, mis proovivad pakkuda oma jüngritele vastuseid kaasaja probleemidele, kuigi erinevalt pinnaselt. New age miksib Ida spiritualismi moodsa Lääne spiritualismi doktriinide ja teosoofiaga, näiteks psühholoogia, kvantfü̈̈sika, bioloogia ja teiste teadustega, mis nende maailmapilti sobivad. New age rõhutab üksikisiku rolli nii iseenda kui ka maailma saatuse määramises, üritades integreerida seda ideed argimõistusse. Uuspaganlik lähenemine on vähem teaduslik ning seda mõjutab rohkem traditsioonide austamine. Uuspaganate rühmad järgivad enda valitud arhailisi usulisi tõekspidamisi ja õpetusi, kohandades need tänapäevale vastavateks. Neid liikumisi ei iseloomusta pü̈̈dlus 
universaalsusele, kuna paganlikud religioonid on juurdunud sügavale rahvusse ja see aspekt seab tihti piirangud jüngrite koosseisule. Mõningates vooludes peab kandidaat läbi tegema initsiatsiooniriituse, mis tähendab, et liikmelisus on new age'i rühmitustega võrreldes eksklusiivsem (Szilágyi 2007, 7).

Teisest küljest aga võrdleb Szilágyi uurimuses "Sacred Characteristics of the Nation" (Rahvuse pühad omadused) poliitilist ja tsiviilreligiooni, määratledes uuspaganlikke liikumisi "ungarluse" väljendusena, mis on lähedane Voeglini (1986) ja Gentile (2004) käsitlustele radikaalsetest parempoolsetest liikumistest kui uute religioossuste manifestist (Szilágyi 2007, 6-7). Lisaks kutsub ta pöörama tähelepanu faktile, et poliitiline religioon, olgu see siis kristliku orientatsiooniga või uuspaganlik, on lahutamatu alternatiivsest historismist ja sakraalgeograafiast, mis on käesoleva uurimuse seisukohalt väga tähtis idee (Szilágyi 2008, 3-5).

Rumeenia uuspaganluse kohta leidub väga vähe teadusuurimusi, kurdab Radu Mureşan ühes üsna hiljutises uurimuses, väites, et teema ei saanud 1989. aastani piisavat tähelepanu (Mureşan 2010, 5). Õigeusupreestri ja ühtlasi ülikooliprofessorina on ta mure pigem misjonärliku loomuga, kuid tema analüüs annab siiski ülitäpse ülevaate värskest religioossest nähtusest. Huvitaval kombel mainib ta aga ainult ühte autohtoonset liikumist: Gebeleizise seltsi, mis on ka käesoleva retoorikaanalüüsi teemaks. Gebeleizis ei ole küll kaugeltki ainus uuspaganate rühmitus Rumeenias, kuid seda on põgusalt mainitud ka ühes teises Rumeenia uurimuses, Cătălin Borangici alternatiivsele ajalookäsitlusele pühendatud "Dacomanias" (Borangic 2008, 133). Ka tema rõhutab sidet protokronismi (Rumeenia erilise ajalootõlgenduse vormi), radikaalse parempoolsuse ja etnotsentrilise religioossuse vahel (Borangic 2008, 127-128, 134).

\subsection{Nähtuse taust}

\section{a) Historistlik kontekst: protokronism romantilise müüdi ja riikliku doktriini vahel}

Mõistmaks pinnast, millest on võrsunud meie etnopaganlikud usuliikumised, peame arvestama nende tagasiulatumisega vähemreligioossete historistlike ideedeni. Nagu ülalpool välja toodud, ei saa me Kesk-ja Ida-Euroopa uuspaganlikke liikumisi uurides jätta kõrvale etnilist elementi, veel vähem ajaloolist aspekti. Mitmed 
Rumeenia ja Ungari, samuti välismaised ajaloolased, sotsioloogid, keeleteadlased, antropoloogid, poliitikateadlased ja muud spetsialistid on uurinud kohalike rahvusluste keskset elementi, eenduvat etnotsentrismi ja selle seoseid religiooni, kultuuri ja ideoloogiaga.

Etnotsentrismi või veelgi radikaalsema etnilise ülimuslikkuse idee avaldub eri vormides kui teatud sorti geograafiline, kultuuriline või ajalooline etnilise entiteedi esmasus, mis on alati suunatud teiste etniliste rühmade vastu. Sellise etnotsentrismi erinähe on protokronism, mis käib mõneti käsikäes mainitud järjepidevuse teooriaga. Protokronism tähendab põhimõtteliselt oma riigi ajaloo heroiseerivat idealiseerimist. Kuigi nii nimetatakse nähtust vaid Rumeenia erialakirjanduses, on see olemas ka Ungaris (samuti teiste selle Euroopa piirkonna rahvaste mõttemallides). Cătălin Borangic avab termini: "[protokronism] on kultuurisuund, mis ilmnes selle nime alla Rumeenias möödunud sajandi seitsmekümnendatel aastatel, kuid see ei ole täiesti uus idee, vaid elustab teatud sorti natsionalismi; seda tendentsi võib täheldada kultuurides, mis nõuavad endale õigust omistatud identiteedile." (Borangic 2008, 119-137.)

Mitmed Rumeenia uurijad on sellest nähtusest kirjutanud raamatuid (Boia 1999, 86-90; Tomiţă 2007; Verdery 1994, 152-204), on ilmunud ka analüütilisi artikleid (Babeş 2003; Olteanu 2007; Borangic 2008; Petre 2001; Spiridon 2001), kus jälgitakse Rumeenia protokronismi algeid, varast arengut, põlu alla sattumist, taasteket, hääbumist ja revolutsioonijärgseid muutusi. Nicolae Densuşianu (1913) romantilisel idüllilise mineviku ideel on vastuoluline ajalugu. Märkigem vaid mõnda võtmeisikut, kes arendasid Ceauşescu ajastul ametliku kommunistlik-rahvusliku riigiideoloogia ajal edasi pelasgianismi ideed alustades prominentsest tegelastest nagu Edgar Papu või Iosif Constantin Drăgani (leegionär-pagulane!) ja lõpetades tänapäevaste pühendunud Daakia ideoloogideni, nagu Napoleon Săvescu või Octavian Sărbătoare. Lühidalt võib protokronismi vaadelda kui rumeenlaste müütilist ajalugu, nende põlvnemist indoeurooplaste eelsetest Karpaatia, Doonau vürstiriikide, Pontose ja Balkani aladel elanud pelasgidest, kes leiutasid kirjakeele (Tărtăria tahvlid), vallutasid ja tsiviliseerisid Euraasia (jõudes Mongoolia või Jaapanini); hilisemad daaklased ja geedid, traaklaste hõim, andsid maailmale esimese monoteistliku religiooni, kummardades Zalmoxist, Kristuse eelkäijat. Need daaklased, kelle roomlased aastal $106 \mathrm{AD}$ osaliselt vallutasid, elasid üle peaaegu kaks sajandit latinisatsiooni ja kuigi ametlik ajalugu õpetab, et latiniseerimise 
protsess oli aluseks rumeenlaste järjepidevuse teooriale, väidavad daakoloogid ja protokronistid, et latiniseerimine oli võltsdoktriin ning rumeenlased on otsesed daaklaste ja geedide järetulijad, kellest viimaseid peetakse ka osaks Rooma langusel rolli mänginud gooti hõimudest. Loomulikult on sellel stsenaariumil palju variante sõltuvalt iga daakoloogi isiklikest uskumustest, kuid põhijooned lähtuvad siiski nendest ideedest.

Väärib märkimist, et kuigi protokronism oli Rumeenias sallitud ja totalitarismiajastul suruti seda isegi ametliku ajalookäsitlusena peale, ei ole Ungaris protokronismi-sarnased doktriinid suutnud kunagi tungida ametlikku riigiideoloogiasse. 19. sajandi algul üritati taasluua väidetavalt kaotatud rahvuslikku mütoloogiat ning peeti keele- ja ajalooalaseid debatte ungari keele ja ungarlaste päritolu ja kuuluvuse üle (tuntakse akadeemilises teadusloos ka ugri-türgi sõjana). Ametlikud ajaloolised doktriinid tõrjusid igatahes kindlalt sküüdi, hunni, türgi ja ungari järjepidevuse teooriat, mis valmistas pettumuse paljudele teooria pooldajatele. Nad ei andnud aga kunagi alla. 20. sajandi algul asutati teaduslikel alustel ja eesmärkidel Turaani selts, mis kuulutas põlvnemist Kesk-Aasiast ja sidemeid madjaritega. Seltsi kuulus palju prominentseid isikuid, nagu Pál Teleki, Béla Széchenyi, Mihály Károlyi, Ármin Vámbéry, Jenô Cholnoky, Ignác Goldziher (Kincses 1991). Pärast Esimest maailmasõda kaotas turanism veidi oma olulisust, kuid muutus samas teaduslikust organisatsioonist poliitiliseks. Väiksem rühmitus üritas isegi luua turaani religiooni, taaselustades ja taastades arhailisi eluviise, moraali ja tavasid (Kincses 1991). Miklós Horthy režiim seltsi siiski ei sallinud ja pärast põgusat taaselustamist Teise maailmasõja ajal see lihtsalt hajus, seltsi võtmetegelased põgenesid välismaale.

Turanism ei ole siiski Ungari protokronismi põhiidee. ${ }^{4}$ Seda toetasid ideed Sumeri päritolust, mida edendasid sellised õpetlased nagu Jós Ferenc Badiny (1998) ja Ida Bobula (1961). Sumerism on tänapäeval alla neelanud peaaegu kõik soome-ugri vastased trendid, aga mis kõige olulisem, Badiny Jeesuse Partia päritolu väitev töö on ajendanud tugeva religioossuslaine (Badiny 1998). Protokronism on leidnud väljenduse religioosses esmasuses aabrahamlike monoteismide suhtes, väites, et Jeesus oli Zarathustra sarnane valguseprohvet. Teised ajaloolised ja kultuurilised esmasused sisaldavad ungari keele ja rahva primaarsust, kirjakeele ja hobustega

${ }^{4}$ Käesolevas artiklis kasutame ka Ungari ajaloolise ja kultuurilise esmasuse ideede tähistamiseks terminit protokronism. 
ratsutamise leiutamist ning lisaks hiljutist huvitavat ideed geograafilisest esmasusest ja järjepidevast asustusest Karpaatides ja Doonau alal - Rumeenia protokronismi diskursusega võisteldes ja teineteist välistades.

Võrdluseks Rumeenia protokronistlike ideedega jätkame lühidalt Ungari protokronistliku mütoloogia variatsioonidega (vt ka Hubbes 2010). Rääkides selle algupärast vastandina ametlikule Uurali ning soome-ugri variandile, pärinevad ungarlased kas protoaasia rahvast(est) ja/või sumerlastest, hunnidest, sküütidest, partialastest, sabirlastest (vt Götz 1989; Bobula 1961; Kiszely 2001; Padány 1963; Pap 1999) või mõningate uuemate teooriate kohaselt ürgsetest protoeuroopa (Karpaatia ja Doonau) rahvastest (Cser; Darai 2005). Selle idee kohaselt on ungari keel säilitanud täiuslikult algupärase protokeele kõige iidsema vormi (Kiss 1999; Varga 2005), tuginedes selle keele ilmselgetele loogilistele iseärasustele oli ungari ruunidel põhinev rovás kõige esimene kirjakeele vorm üldse ja ülejäänud tähestikud arenesid välja just sellest (vt Varga passim; ungari ruunikirja kohta vt Maxwell 2004). Seega on see rahvas eelajaloolise protokultuuri otsene järeltulija, samal ajal kui ülejäänud rahvad ümberringi hajusid ja mandusid (vt tamana teooria kohta VámosTóth 2010). Selle loogika järgi ei tohiks olla mingi üllatus, et just ungarlased olid tõelised (Partia) "eelkristliku kristluse" algatajad ja põlistajad. Jeesus ise oleks selle kohaselt Partia prints, kes tõi maailmale sõnumi valgusest, mille seejärel rikkus "juutide piibel" (Badiny 1998). Kõige kiuste ja pealesunnitud ristiusustamisest hoolimata suutsid ungarlased siiski Püha Krooni müstilist plaani järgides oma usu päästa ning hoida sakraalset ordut kogu möödunud aastatuhande elus Karpaatide orus (vt Pap 1999). Ungari püha missioon, mille esimene kuningas, püha Stephanus pühendas neitsi Maarjale, on alati olnud valguse ja tõe kaitsjaks ning Ida ja Lääne vaheliseks vaimseks sillaks olemine, samal ajal tõrjudes ülitähtsalt Kesk-Karpaatia alalt eemale nii sissetungijaid ida poolt kui ka läänepoolseid agressiivsed imperialistlikke jõude (vt Balogh 2010).

Neid ideid ei ole Ungari ametlik diskursus kunagi tunnistanud, isegi mitte pärast kommunistliku režiimi langemist. Siiski on need viimasel ajal saavutanud teatud sorti kvaasi-legitiimsuse parempoolsete poliitiliste erakondade kaudu: esiteks Magyar Igazság és Élet Pártja (Ungari Õiglus- ja Elupartei) ja nüüd ka 'Jobbik'-erakonna esilekerkimisega (sõnamäng: "Parempoolsem" = "Parem" Erakond) (Szilágy 2008, 2). 


\section{b) Religioosne kontekst: ülemaailmsest new age'ist külaša- maanide ja eksiilis viibivate zalmoxialasteni}

Pärast kahesajandilist ratsionalismi valitsemisaega vähemalt "suure diskursuse" tasandil asub irratsionaalsus enesele kohta nõudma. Valgustusest alates on teadus müüte halastamatult ümber lükanud, tänapäevane mõtteviis on tõrjunud tunnetusest eemale intuitsiooni, ettekujutuse ja vaimsed kogemused. Postmodernses mõttemaailmas on senised stabiilsed diskursused vankuma löönud, luues sellega vaba tee reaalsuse käsitlemise paljususele (Szilárdi 2007, 72). Juba 19. sajandi teise poole algusest on Lääne mõtlejad üha enam ja enam langenud Ida spirituaalsuse, iidse tarkuse, müstilise gnostitsismi, okultistlike traditsioonide lummusse, hoolimata sellest, kas need on olemas tänapäeva maailmareligioonides või on need taasavastatud ammu unustatud kirjutistest. Lisaks on inimestel tekkinud tugev soov pääseda nn inimlikust tähendusest ja tunnetusest tühjaksvoolanud kirikute jõulisest haardest. Loodus ja keskkond on justkui katte alt vabanenud, entusiastlikult järgitakse eksootiliste vabas looduses elavate hõimude looduslähedasi eluviise. Kõik need protsessid on kumuleerunud suureks vaimseks revolutsiooniks, mida möödunud sajandi kuuekümnendatel aastatel Ühendriikidest alguse saanuna kutsuti vastukultuuriks. Hipid ja spiritistid tunnetasid mõlemad seda kui inimkonna uue ajastu lävepakku, mida nimetati new age (of Aquarius) (Veevalaja uus ajastu). See on endaga kaasa toonud maailma taasmütologiseerimise või taassakraliseerimise, avades ukse arvukatele uutele religioossetele liikumistele.

Just selles ülemaailmses postmodernses kontekstis tuleks mõtestada uuspaganlikke algatusi. Siiski, nagu ülalpool määratletud (Szilágyi 2008, 7), ei tohiks new age'i segi ajada uuspaganlike liikumistega. Ühelt poolt on uuspaganlus enese vabastamine ja liitmine orgaanilise kogukonnaga, teisalt on see püüdlus pääseda lähemale loodusele, esivanematele ja oma juurtele. Etnilise paganluse puhul on püüdlus suunatud kaugemasse minevikku, eelkristlike või võõrmõjutusteta elanud esivanemate tarkuse ja moraalse puhtuse taaselustamisele. Selle loogika kohaselt on võõrmõjud midagi halba, olenemata sellest, kas tegemist on riigi, religiooni, ühiskonna majandusliku formatsiooni, vallutajate jõu või lihtsalt globaliseerumisega. Mõnikord levivad sellised uuspaganalikud ideed kristliku peavoolu alavooludena. Ungari ja Rumeenia etnopaganlikud liikumised kuuluvadki enamasti sellise mudeli alla. ${ }^{5}$

${ }^{5}$ Vt fenomeni Rumeenia ja Ungari konteksti võrdlevat tabelit lisa 2. 
Käsitleme näidete varal kahte põhilist Ungari ja Rumeenia uuspaganluse rekonstruktsionistlikku suundumust, et tuua esile iga tüübi kindlad variandid. Rumeenia mudelit nimetame zalmoxianismiks, kuigi Eliade kirjeldatud traakia vähetuntud zalmoxise usurühmituse selget ja puhast taaselustamist esineb vähe (Eliade 1995). Valisime siiski selle märgi, kuna peaaegu kõik Rumeenia etnopaganlikud liikumised põhinevad daakia-ideedel, mis tingimata sisaldavad Traakia-Daakia esivanemate religioosset vaimsust. Ungari mudelit nimetame samas šamanistlikuks, kuna see on kõige tavapärasem Aasia esivanemate kultuse juurde tagasipöördumise vorm, olenemata sellest, kas end kutsutakse táltos-šamaanideks või tengristideks või põlisungarlasteks. Järgnevalt püüame esitada kokkuvõtte internetis leitavatest etnopaganlikest liikumistest, olenemata nende institusionaliseerituse või organiseerituse astmest.

Rumeenia etnopaganate või protokronistlike daakoloogide põgus internetiülevaade näitab, et suurem osa neist defineerib end daaklastena: Noi Dacii - Revista pentru Limba şi Cultura Dacilor (Daaklaste keele ja kultuuri ajakiri, http://www.noidacii. ro/); Dacii.Info - daaklastele pühendatud veebilehekülg http:// www.dacii.info/; Dacia Nemuritoare: Prima Revistă Dedicată Dacilor Liberi (Surematu Daakia: esimene vabadele daaklastele pühendatud ajakiri, http://www.dacii.ro/revista/); Dacia.org Napoleon Săvescu mõttekaaslaste hallatav veebilehekülg (http:// dacia.org/); Enciclopedia Dacica - daaklastele pühendatud veebientsüklopeedia (http://www.enciclopedia-dacica.ro/statele/ index.html); ROMANIA-DACIA: CASA NOASTRA Blog al Frontului de Eliberare a Daciei (RUMEENIA DAAKIA: MEIE KODU - Daakia vabastamisele pühendatud rindeblogi, http:// casanoastra-romania-dacia.blogspot.com/); Dacologica - daaklastele pühendatud blogi (http://studiidacologice.com/); Dacii lui Zamolxe - daakia zamolxile pühendatud veebifoorum (http://dacii-luizamolxe.wikiforum.ro/); Spiritualitate Daco-Românească: Reabilitarea tradiţiilor şi spiritualităţii autohtone autentice (Daakia-Rumeenia Vaimsus - autentsete põliskommete ning vaimsuse taastamine - blogi, http://spiritualitatedacoromaneasca. wordpress.com/). Ammendamata umbes kahekümnest sarnasest Rumeenia rühmitusest ja veebileheküljest koosnevat nimekirja, võime üldistada, et nende lehekülgede liikmed ja kaastöölised ei identifitseeri end üldiselt praktiseerivate uuspaganate või kindlate kultuste rituaalide järgijatena. Siiski näitab nende lehekülgede, blogide ja foorumite üldkuvand tugevat seotust arhailise Daakia- 
Zalmoxia vaimsuse ja religiooni taaselustamisega (ilma selliste ekstreemsete ettepanekuteta nagu näiteks pagulase Octavian Sărbătoare ettepanek muuta zalmoxianism Rumeenia ametlikuks riigireligiooniks). On siiski olemas organisatsioon, mis kuulutab avalikult enda uuspaganlikku, Daakia juurtega identiteeti Gebeleizis (http://www.gebeleizis.org/main.htm). Järgnevalt analüüsime detailsemalt organisatsiooni, mis on nimetatud Zalmoxise teise (arvatava) nime järgi, mis on ühtlasi traaklaste kõuejumala nimi.

Ungari šamanistlike veebirühmituste samasugune nimekiri sisaldab palju sõnamänge, mis viitavad ungari keele sakraalsele olemusele või viiteid ungari (madjari) esivanematele või ungarlastele endile: Magtár (http://magtar.atw.hu/); Magyarságtudományi Intézet (Ungari uurimuste instituut, http://www.magtudin.org/ index.htm); Magyar Harcos (Ungari sõdalane, http://magyarharcos. hu/). Osa lehekülgedest, blogidest või foorumitest defineerib end juba pealkirjades kui kirikuid või religioone (http://www.osmagyaregyhaz. hu/); "Táltos" tähendab šamaani (http://www.taltos7.hu/; http:// www.taltossaman.hu/; http://vhk.saman.org.hu/; http://osszefogas. ewk.hu/taltos; http://zsaratnok.org/) ning "Yotengrit" ja "Arvisura" (http://arvisura.freeweb.hu/lib/barasits.htm (ei ole kättesaadav, toim); http://arvisura.lap.hu/; http://tengri.hu (ei ole kättesaadav, toim); http://www.yotengrit.com/ (piiratud ligipääsuga, toim)) märgivad kahte Ungarile eriti iseloomulikku religioosset nähtust mõlemad põhinevad šamanistlikul vaimsusel, Ungari protokronismi fantaasiaküllasel mütoloogial ja neil on tugev side new age'i mentaliteediga. Tamana on tüüpiline protokronistlik teooria, mis propageerib ungarlasi eelajaloolise maailmarahvusena, kes jättis toponüümide abil endast kõikjale märke, ja loomulikult on olemas ka Tamana-rühmitused. Vastupidiselt Rumeenia analoogidele, on need rühmad üsna religioossed ja viivad uuspaganlikel festivalidel läbi šamanistlikke rituaale. Samal ajal on enamik neist tüüpilised etnopaganad, kes keskenduvad eelkõige Aasia steppidest pärinevate religioossete traditsioonide rekonstrueerimisele.

\section{c) Tehnoloogiline kontekst: sotsiaalmeediabuum ja veeb 2.0}

1990. aastate keskpaigast saadik asus internet võõrustama ning ülal hoidma uuspaganlike rühmituste ja isikute virtuaalsete kogukondade loomist, seda mitte silmast silma vaid "kujutletud kogukondadena" (Grieve 1995, 87). Need rohkem või vähem kohesiivsed indiviidide ja rühmade kogumid moodustuvad sarnaste väärtus- 
hinnangute ja tavade jagamise alusel ning individualiseeruvad "kujutletud rituaalide" abil (Grieve 1995, 95).

Aastatel 1995-2002 oli internetil meediumina vähem interaktiivseid omadusi: staatilised veebilehed, arutelu-listid, foorumid ja e-mailid. 2003. aastast peale on veebikeskkonnad ümber kujundatud eelkõige selliste veebirakenduste tõttu nagu blogid (Blogspot, Wordpress), wikid, interneti videojagamisleheküljed (YouTube), mikroblogid (Twitter) ja sotsiaalmeedia keskkonnad (MySpace, Facebook). Neil veeb 2.0 vahenditel on tugev mõju sotsiaalsele suhtlusele, aidates kasutajate loodud sisu levikule kaasa ennenägematus mahus. Termin "Veeb 2.0", mille mõtles välja Darcy deNucci ja mida populariseeris Tim O’Reilly $(2007,17)$, määratleb uue põlvkonna veebipõhiseid jooni: need võimaldavad interaktiivsust, kasutajale suunatud disaini ja virtuaalsete kogukondade loomist. Ei ole üllatav, et pärast veeb 2.0 põhiste rakenduste levikut on rahvusvaheline uuspaganluse uurimine tuvastanud märkimisväärse üksikharrastajate arvu kasvu (51 protsendilt 79 protsendile), nagu eelpool mainitud (Berger 2010, 1).

Veebiretoorika analüüs on tugevalt seotud veebilehekülje usaldusväärsuse hindamisega, mis muutub järjest raskemaks ülesandeks kollektiivse autorsuse ja koostöös valminud sisu tõttu (Warnick 2007, 15). Siiski hõlbustab veeb 2.0 interaktiivsus märkamatut online uurimistööd ja organisatsioonilise suhtluse peenekoelist vaatlust.

\section{Etnopaganate veebiretoorika - empiiriline analüüs}

Vastamaks uurimuse esimesele küsimusele zalmoxislike ja šamanistlike rühmituste veebiretoorika sarnasustest ja erinevustest, esitame kahte sorti analüüsi: ühelt poolt vaatleme veebiretoorika stiili ning võrdleme ühte Rumeenia ja ühte Ungari etnopaganlikku organisatsiooni kolme üldkriteeriumi alusel. Selle analüüsi eesmärk on määrata, kas nad kasutavad veeb 2.0 võimalusi (Deuze 2003, 203) või pigem traditsioonilisi vahendeid (Hocks 2003, 629). Teiselt poolt vaatleme pisut sügavamalt nende organisatsioonide veebiretoorika esitamist, lähtudes klassikalisest organisatsioonidele suunatud aristoteleslikust raamistikust (Hoffman, Ford 2010, 49). Selleks oleme valinud kaks etnopaganlikku organisatsiooni, mis on üsna samal tasemel kogukonna institutsionaliseerumise, välja- 
kujunenud väärtussüsteemi (Shirky 2008, 143) ja liikmete osaluse poolest (Lichbach 2001, 17). Võrdlusalused on Ungari šamanistlik organisatsioon Tengri (http://tengri.hu) ja Rumeenia zalmoxiseorganisatsioon Gebeleizis (http://gebeleizis.org/). Kuigi viimane on sattunud meediaskandaalidesse (Lupu 2007) ja teda süüdistatakse tihti seaduserikkumistes ja neonatslike väärtuste propageerimises (Stanciu 2005), on see siiski kõige nähtavam Rumeenia rühm, mis määratleb end esiteks paganlikuna ja teiseks kultuurilise organisatsioonina, vastupidiselt näiteks Sarmizegetusa ühingule või Daakia Rahvusvahelise Taassünni rühmitusele.

\subsection{Rumeenia ja Ungari etnopaganlike organisatsioonide veebiretoorika stiil}

Nagu väidab Mary Hocks (2003, 629), ei ole visuaalse retoorika kasutamine veenmiseks kaugeltki uus kommunikatsioonistrateegia, kuid selle olulisust on võimendanud hüperteksti ja multimeediakirja visuaalne ja interaktiivne iseloom. Hocks on välja töötanud põhjaliku raamistiku analüüsimaks internetis olevate digitaalsete keskkondade retoorilist stiili (Hocks 2003, 632).

I. Publiku hoiak. Viisid, kuidas publikut kutsutakse osalema online-dokumentides/kirjutistes ja viisid, kuidas autor loob eetose, mis nõuab, julgustab või isegi tõrjub publiku erinevat interaktiivsust.

II. Läbipaistvus. Viisid, kuidas veebis olevad kirjutised suhestuvad juba väljakujunenud konventsioonidega, nagu näiteks trükiste, graafilise disaini, filmide ja veebilehekülgedega. Mida rohkem veebikirjutis laenab tuttavatest konventsioonidest, seda läbipaistvam on ta publikule.

III. Hübriidsus. Viisid, kuidas veebikirjutised kombineerivad ja loovad visuaalseid ja verbaalseid kujundeid. Hübriidsus julgustab ühtlasi nii autoreid kui ka publikut tunnustama ja looma mitmekülgseid identiteete.

Mary Hocksi visuaalse retoorika analüüsi raamistik ühtub Marc Deuze $(2003,206)$ välja töötatud võrguajakirjanduse ja veebivälise ajakirjanduse võrdluse kriteeriumitega: interaktiivsus (auditooriumi hoiak), hüpertekstuaalsus (läbipaistvus) ja multimediaalsus 
(hübriidsus). Kasutame seda raamistikku Rumeenia ja Ungari etnopaganlike organisatsioonide veebikeskkondades kasutatavat retoorikat võrdlemiseks ja vastandamiseks. Visuaalsel retoorikal, mis kasutab eelkõige traditsioonilisi tekstile keskendunud trükimeedia vahendeid (kutsugem seda veeb 1.0 retoorikaks) on madal publiku kaasamise tase (madal interaktiivsus), kõrge läbipaistvuse tase (napp ja peamiselt staatiline hüpertekstide või linkide kasutus, viimaks publikut uute küberruumideni) ja madal hübriidsuse tase (kasin ja eeskätt staatiline multimeediakasutus, nt piltide kuvamine). Ruumi antakse rohkem tavatekstile kui hüpertekstile.

Selle vastandina on veeb 2.0 retoorikal kõrge publiku kaasamise tase (see on väga interaktiivne), madal Hocksi poolt defineeritud läbipaistvuse tase (Hocks 2003, 629), sest tavateksti asemel leiame hüpertekstuaalselt organiseeritud informatsioonikobara, ning kõrge hübriidsuse tase, kuna kasutatakse ulatuslikult multimeediavahendeid ja -kanaleid: pilte, slaidiesitlusi, helisid, videoid ja palju jagamisvõimalusi (Twitteri, Facebooki, Deliciousi ja muude veebirakenduste jaoks).

Mõlemal uuritaval etnopaganlikul organisatsioonil - Rumeenia zalmoxise-rühmal Gebeleizise ühing ja Ungari šamanistlikul rühmitusel Tengri Babba Kogukond, on hästidokumenteeritud veebileheküljed, millel on tugev visuaalne isikupära ja rohke ingliskeelne sisu, mis vihjab nii eneseavamisele rahvusvahelise publiku ees kui ka tõestab vaimsete liidrite sidemeid välismaaga.

Gebeleizise ühingu veebileheküljel domineerivad tumedad värvitoonid, detailselt on selgitatud iidseid paganlikke sümboleid ja rida sõjasümboleid, mida on varjamatult seotud skandinaavia mütoloogiaga, ka on Rumeenia rubriigipealkirjad trükitud skandinaavia ruune meenutavas kirjas. Veebilehekülje pealkiri viitab ultraparempoolsetele ülimuslikele väärtustele: $\ddot{U} k s$ perekond, $\ddot{u k s}$ rahvus, üks territoorium. Veebikülje kujundus ja korraldamine on kuulutatud Hank Schmidti intellektuaalseks omandiks. Otsingumootorite abil leidsime, et domeeni nimi on registreeritud sama isiku poolt Floridas, USAs. Siiski on organisatsiooni kõige nähtavam liige Andrei Molnar, üks kolmest kaasasutajast, kes on tuntud avaliku konflikti tõttu Rumeenia politseiga ja kes on Rumeenia võimudega kohut käinud. 


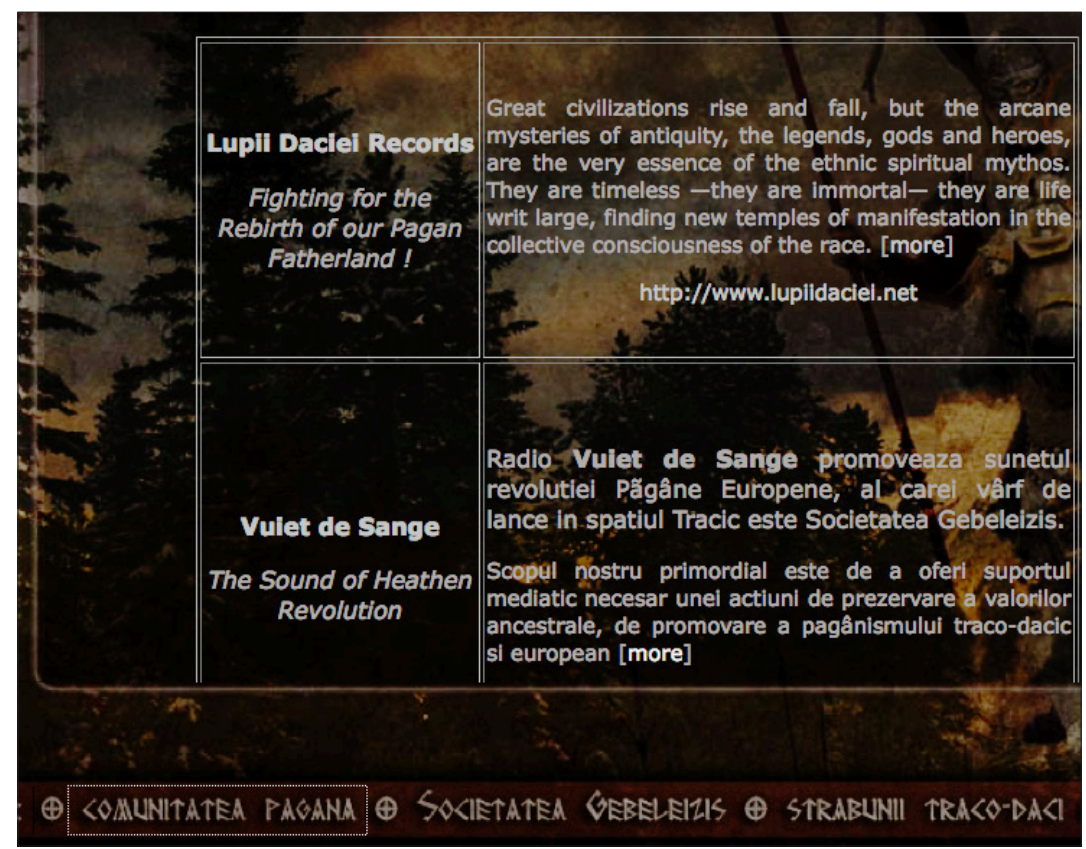

Joonis 1. Näidis Gebeleizise veebilehe Pagan Community (Paganate kogukonna) menü̈̈st.

Tengri Babba Kogukonna internetikülje kujundus põhineb heledamatel värvidel, navigatsiooninuppudel on kujutatud uhkeid iidseid mütoloogilisi sümboleid: šamaanitrumm, (ungari) ruunid. Lehe keskel asub elupuu, mis viitab sidemele maa ja taeva vahel. Looduselemente korratakse fotodel, joonistustes ja tekstides. Veebilehekülje pealkiri - Sólyomfi Nagy Zoltán - on kogukonna guru nimi. Suurem osa veebilehe sisust on tema allkirjastatud, sealhulgas isegi audiosisu (liidri kirjutatud ja koos temaga esitatud rahvalauluimitatsioonid). 


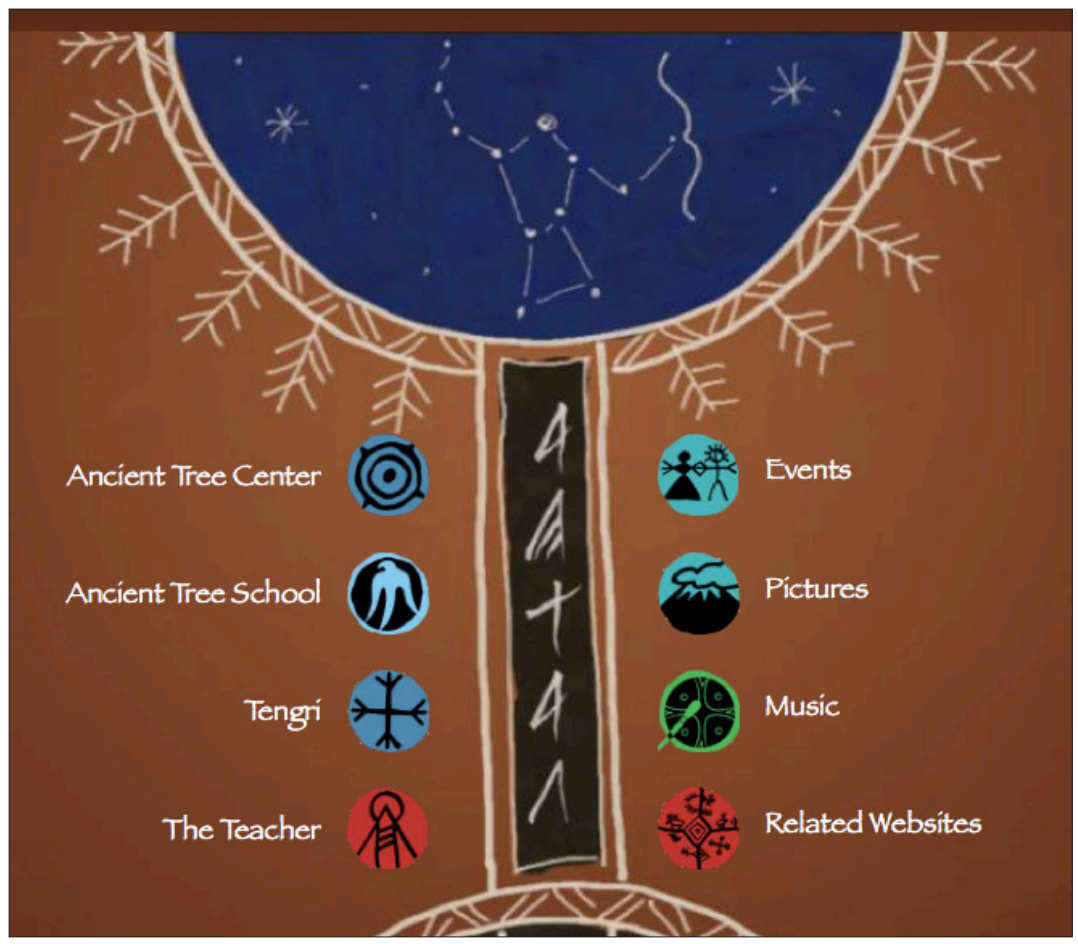

Joonis 2. Tengri Babba Kogukonna avaleht.

Peale ülalpool esitletud veebiretoorika stiili hindamise raamistiku kasutamist võtame ulatuslikus tabelis kokku kahe etnopaganliku organisatsiooni interaktiivsuse, hüpertekstuaalsuse ja multimediaalsuse taseme. 
Tabel 6. Uuritavate etnopaganlike organisatsioonide veebiretoorika stiil

\begin{tabular}{|c|c|c|}
\hline $\begin{array}{l}\text { Analüüsi } \\
\text { kriteeriumid }\end{array}$ & Gebeleizise Ühing & Tengri Babba Kogukond \\
\hline $\begin{array}{l}\text { Publiku } \\
\text { hoiak (inter- } \\
\text { aktiivsus) }\end{array}$ & $\begin{array}{l}\text { Keskmine kuni } \\
\text { madal tase: } \\
\text { meiliaadress ja } \\
\text { mobiilinumber, } \\
\text { e-mailiga kaupade } \\
\text { tellimine, } \\
\text { Moneybookers ja } \\
\text { pangaülekanded } \\
\text { (postkaardid, } \\
\text { kalendrid, raamatud } \\
\text { ning T-särgid) }\end{array}$ & $\begin{array}{l}\text { Keskmine kuni madal } \\
\text { tase: meiliaadress ja } \\
\text { mobiilinumber, suletud } \\
\text { foorum registreeritud } \\
\text { kasutajatele, e-mailiga } \\
\text { kaupade tellimine } \\
\text { (šamaanitrummid, } \\
\text { kodus valmistatud } \\
\text { esemed, heliplaadid) }\end{array}$ \\
\hline $\begin{array}{l}\text { Läbipaistvus } \\
\text { (teks- } \\
\text { tuaalsus) }\end{array}$ & $\begin{array}{l}\text { Madal: mittetöötavad } \\
\text { lingid Väljaannete } \\
\text { rubriigis, } \\
\text { navigeerimine } \\
\text { keeruline, puuduvad } \\
\text { otsinguvahendid, } \\
\text { väga madal varundus: } \\
\text { raske saada } \\
\text { alguspunkti tagasi }\end{array}$ & $\begin{array}{l}\text { Keskmisest } \\
\text { madalani: intuitiivsed } \\
\text { navigatsiooninupud, } \\
\text { kuid otsinguvahendid } \\
\text { puuduvad, keeruline } \\
\text { navigeerida, väga madal } \\
\text { varundus: raske saada } \\
\text { alguspunkti tagasi }\end{array}$ \\
\hline $\begin{array}{l}\text { Hübriidsus } \\
\text { (multi- } \\
\text { meedialisus) }\end{array}$ & $\begin{array}{l}\text { Keskmine: } \\
\text { tekstipõhine disain } \\
\text { mõningate veeb } \\
2.0 \text { vahenditega: } \\
\text { muusika voogesitus, } \\
\text { link uudistesaidile } \\
\text { nimega Thracia } \\
\text { Identitarian } \\
\text { Press Agency } \\
\text { (TIPA). Puuduvad } \\
\text { videod, napid } \\
\text { jagamisvahendid } \\
\text { - ainult Facebooki } \\
\text { TIPA link }\end{array}$ & $\begin{array}{l}\text { Keskmisest madalani: } \\
\text { tekstipõhine disain ilma } \\
\text { veeb } 2.0 \text { vahenditeta } \\
\text { (jagamine, video). } \\
\text { Saadaval heli voogesitus } \\
\text { guru muusikale }\end{array}$ \\
\hline
\end{tabular}


Kokkuvõtteks võib öelda, et mõlema organisatsiooni veebilehed on veeb 1.0 staadiumis, kus neil on minimaalne publiku osalus, kasin hüperteksti või ristlinkimise võimalus ning napp multimeediavahendite (video või jagamisvõimaluste) kasutus.

\subsection{Etnopaganlike organisatsioonide retoorika}

Veebiretoorika üksikasjalikumaks analüüsiks sobib hiljuti Mary Hoffmani ja Debra Fordi $(2010,49-50)$ poolt organisatoorse retoorika jaoks kohandatud aristoteleslik raamistik. Organisatoorse veebiretoorika võrdlevaks analüütiliseks hindamiseks sai valitud aristotelesliku retoorika põhikategooriad: eetos, logos ja paatos. Mõlemad organisatsioonid teevad silmanähtavaid pingutusi, et luua usaldusväärsus (eetos), veenda üldsust organisatsiooni väärtustes ja tekitada oma eesmärkidele ratsionaalseid väiteid. Religioossed organisatsioonid soovitavad tegevusi ja kindlaid kultuurilisi tegevusi ning propageerivad kindlat eluviisi. Nende veenmisvahendite võtmeomadused võtab kokku tabel 7.

Kuigi mõlemad etnopaganlikud organisatsioonid on institutsionaliseerituse astme ja väärtuste selguse poolest võrreldaval tasemel ning tegutsevad etniliste väärtuste legitimiseerimise nimel, toob võrdlus välja rohkem erinevusi kui sarnasusi. Eetos ja sotsiaalne legitimiseerimine näitavad Rumeenia organisatsiooni puhul bürokraatliku lähenemist ning Ungari organisatsiooni puhul traditsioonilist, karismaatilist lähenemist.

Olulisi erinevusi leidus ka paatosega seonduvates elementides: Rumeenia paganlik organisatsioon otsib tõdesid ja juuri PõhjaEuroopa sõdalasmütoloogiatest, Ungari šamanistlikud rühmad seostavad ennast rohkem Kesk-Aasia traditsioonidega. Ka õhutasid uuritud zalmoxislikud noored rohkem vastasseisu ja pooldasid poliitikas pigem ultraparempoolset etnilise ülimuslikkuse diskursust, seevastu tengrismi šamanistlik rühm oli poliitiliselt neutraalsem, seda võib-olla keskealise guru tõttu. Tõenduste ja põhjenduste poolest erinevad ka argumenteerimisstrateegiad: tengri-kogukond üritab veenda pigem näidete abil (esitatud on suur hulk tegemisi ja guru CV), sellal kui zalmoxia rühmitus võitleb rohkem religioosse ja poliitilise status quo ning asutamisdokumentide deduktiivsete argumentidega.

Empiirilise analüüsi kitsa käsitlusala tõttu on sel rohkem heuristiline funktsioon: tõstatada küsimusi ja oletusi tulevaste uurimuste 
Tabel 7. Uuritavate etnopaganlike organisatsioonide veebiretoorika esitus

\begin{tabular}{|c|c|c|c|c|}
\hline $\begin{array}{l}\text { Aristotelese } \\
\text { retoorilised } \\
\text { kategooriad }\end{array}$ & \multicolumn{2}{|c|}{$\begin{array}{l}\text { Organisatoorses retoorikas } \\
\text { leitud vormid }\end{array}$} & $\begin{array}{l}\text { Gebeleizise } \\
\text { Ühing }\end{array}$ & $\begin{array}{l}\text { Tengri Babba } \\
\text { Kogukond }\end{array}$ \\
\hline $\begin{array}{l}\text { Eetos/ } \\
\text { Usaldus- } \\
\text { väärsus }\end{array}$ & \multicolumn{2}{|c|}{$\begin{array}{l}\text { Organisatoorne sotsiaalne } \\
\text { legitiimsus: } \\
\text { kompetents, kogukond }\end{array}$} & $\begin{array}{l}\text { Põhikiri } \\
\text { avaldatud, } \\
\text { ajalooline } \\
\text { taust }\end{array}$ & $\begin{array}{l}\text { Guru CV } \\
\text { veebis olemas; } \\
\text { vaimne taust }\end{array}$ \\
\hline \multirow[t]{10}{*}{$\begin{array}{l}\text { Paatos/ } \\
\text { Emotsioon }\end{array}$} & \multirow{4}{*}{$\begin{array}{l}\text { Väärtuste } \\
\text { propageeri- } \\
\text { mine }\end{array}$} & $\begin{array}{l}\text { Otsesed } \\
\text { nõuded }\end{array}$ & $\begin{array}{l}\text { Vastandav } \\
\text { toon }\end{array}$ & $\begin{array}{l}\text { Enesekindel } \\
\text { toon }\end{array}$ \\
\hline & & $\begin{array}{l}\text { Jagatud } \\
\text { väärtused }\end{array}$ & $\begin{array}{l}\text { Põhja- } \\
\text { Euroopa }\end{array}$ & Kesk-Aasia \\
\hline & & $\begin{array}{l}\text { Heategevus- } \\
\text { likud } \\
\text { üritused }\end{array}$ & $\begin{array}{l}\text { Rokk- } \\
\text { kontsertid }\end{array}$ & $\begin{array}{l}\text { Loengud, } \\
\text { reisid }\end{array}$ \\
\hline & & $\begin{array}{l}\text { Isikute } \\
\text { kiitmine }\end{array}$ & $\begin{array}{l}\text { Vastuvõtmis- } \\
\text { riitus }\end{array}$ & $\begin{array}{l}\text { Vastuvõtmis- } \\
\text { riitus }\end{array}$ \\
\hline & \multirow[t]{5}{*}{$\begin{array}{l}\text { Samas- } \\
\text { tamine }\end{array}$} & $\begin{array}{l}\text { Samas- } \\
\text { tamine }\end{array}$ & $\begin{array}{l}\text { Paganlik/ } \\
\text { daaklik }\end{array}$ & $\begin{array}{l}\text { Šamanistlik/ } \\
\text { ungarlik }\end{array}$ \\
\hline & & Antitees & $\begin{array}{l}\text { Välistavad } \\
\text { toonid }\end{array}$ & $\begin{array}{l}\text { Kaasaarvav } \\
\text { diskursus }\end{array}$ \\
\hline & & $\begin{array}{l}\text { Ühised } \\
\text { jooned }\end{array}$ & $\begin{array}{l}\text { "Veri", } \\
\text { rahvus- } \\
\text { kuuluvus }\end{array}$ & $\begin{array}{l}\text { Tavad, } \\
\text { rahvus- } \\
\text { kuuluvus } \\
\end{array}$ \\
\hline & & $\begin{array}{l}\text { "Meie" } \\
\text { määratlus }\end{array}$ & $\begin{array}{l}\text { Paganlik/ } \\
\text { daaklik }\end{array}$ & $\begin{array}{l}\begin{array}{l}\text { Šamanistlik } \\
\text { ungarlik }\end{array} \\
\end{array}$ \\
\hline & & $\begin{array}{l}\text { Ühendavad } \\
\text { sümbolid }\end{array}$ & $\begin{array}{l}\text { Põhja- } \\
\text { Euroopa }\end{array}$ & Kesk-Aasia \\
\hline & \multicolumn{2}{|l|}{ Vajadused } & $\begin{array}{l}\text { Võimu- } \\
\text { organite } \\
\text { eitamine }\end{array}$ & $\begin{array}{l}\text { Võimu- } \\
\text { organite } \\
\text { aktsepteeri- } \\
\text { mine }\end{array}$ \\
\hline Logos & \multicolumn{2}{|c|}{ Väited, tõestus, põhjendus } & $\begin{array}{l}\text { Deduktiivne } \\
\text { põhjenda- } \\
\text { mine, } \\
\text { protokronism }\end{array}$ & $\begin{array}{l}\text { Induktiivne } \\
\text { põhjenda- } \\
\text { mine, karisma }\end{array}$ \\
\hline
\end{tabular}


jaoks. Kas etnopaganate osalemine poliitikas oleneb ajastust või pigem juhtimisstiilist ja põhiväärtustest? Kas Ungari uuspaganlikud organisatsioonid üritavad kasutada rohkem karismaatilist õigusjärgsust, sellal kui Rumeenia organisatsioonid eelistavad pigem bürokraatlikke vahendeid? Marcel Pousti laadis: võib-olla ei tähenda avastamine üksnes uute alade otsimist, vaid pigem asjade vaatamist uue pilguga.

\section{Kokkuvõtted}

Meie eesmärk oli hinnata Rumeenia ja Ungari etnopaganlike organisatsioonide põhilisi sarnasusi ja erinevusi. Eesmärgi täitmiseks sooritasime avalikult kättesaadava informatsiooni alusel organisatsioonide võrdleva teoreetilis-empiirilise analüüsi.

Esimesele uurimisküsimusele zalmoxia ja šamanistlike rühmituste veebiretoorika erinevuste ja sarnasuste kohta vastasime kahte hindamisvahendit kasutades. Esimene neist oli seotud etnopaganlike organisatsioonide veebilehtede interaktiivsuse, hüpertekstuaalsuse ning multimediaalsuse määraga, teine jälgis internetikontekstile mugandatud kolme aristotelesliku retoorikakriteeriumi - eetose, paatose ja logose - kasutamist. Sarnasusi esines rohkem veebiretoorika stiilis ning erinevusi veebiretoorika esituses. Nii zalmoxislikud kui ka šamanistlikud organisatsioonid kasutavad endiselt veeb 1.0 tunnuseid (madal interaktiivsuse, hüpertekstuaalsuse ning multimeedialisuse tase). Eetose puhul leidsime erinevat legitimiseerimisstrateegiad ning paatos tugines erinevale kultuurilisele päritolule, lahknesid ka argumentatsioonitehnikad.

Teine uurimisküsimus käsitles zalmoxia ja šamanistlike rühmituste seotust poliitiliste ja sotsiaalsete liikumistega. Suurem osa uuritud veebilehekülgedest osutas, et protokronismile suunatud zalmoxise-rühmad väljendavad küll poolehoidu radikaalsele parempoolsusele ja on seostatavad vastavate lehekülgedega, kuid otsene seos nendega üldiselt puudub. Gebeleizise näide on pigem erand, kus uuspaganlus, etnotsentrism ja läbivalt ultraparempoolne ideoloogia leiavad silmapaistva väljundi. Ungari šamanistlike liikumiste palett on oluliselt ebamäärasem. Kui rühmitusel on sügavam huvi paganlike religioossete ideede vastu, siis sellevõrra väiksem on nende poliitiline aktiivsus. Tengri kogukonna lehekülg on selle hea näide, kuigi ka sealt ei puudu poolehoiuavaldused protokronistlikule mõtteviisile ja parempoolsele ideoloogiale. 
Kolmas uurimusküsimus seostus etnopaganlike rühmade ja liikumiste institutsionaliseerituse tasemega - kas nad tegutsevad registreeritud organisatsioonide või mitteametlike rühmadena. Leidsime, et institutsionaalse legitiimsuse saavutamiseks on tehtud arvestatavaid pingutusi, registreerides organisatsioonid õigusjärgsete üksustena, ${ }^{6}$ samuti on tehtud püüdlusi isiklikul tasemel, nagu osutavad rahvusvahelised suundumused paganate loendamisel.

Neljas uurimisküsimus vaatles, mil määral määratlevad etnopaganlikud rühmitused endid religioossena ja mil määral etnopoliitilisena. Pärast paljude mõlema poole veebilehtede läbivaatamist võib järeldada, et Rumeenia rühmitustele on Traakia idee olulisem kui hägune religioosse kultuse struktuur ning nad on koondunud pigem nende poolt zalmoxislikuks vaimsuseks nimetatu ümber. Sellele vastandina määratlevad reaalse šamanismiga seonduvad Ungari šamanistlikud rühmitused end pigem religioossena, etnopoliitiline tegevus on teisejärguline.

\section{Tõlkinud Alo Ailt}

\section{Kirjandus}

Adler, Margot 1979. Drawing Down the Moon: Witches, Druids, GoddessWorshippers, and Other Pagans in America. New York: Viking.

Ágoston, Dániel 2009. A Pogány torony. - Óstörténeti írás gyuújtemény, 6 March (http://ostortenetunk.blogspot.com/2009/03/pogany-torony. html - ei ole enam leitav).

Ágoston, Vilmos 2008.Magyarés román szélsôséges honlapok. Múhelytanulmány 35. Budapest: Európai Összehasonlító Kisebbségkutatások Közalapítvány (http://www.eokik.hu/data/files/123541492.pdf 24.04.2013).

Babeş, Mircea 2003. Renasterea Daciei? - Observator Cultural 185 (http:// www.observatorcultural.ro/Renasterea-Daciei*articleID_9072articles_details.html - 18.05.2013).

Badiny, Jós Ferenc 1998. Jézus király - A pártus herceg. Budapest: Ốsi Örökségünk Alapítvány.

${ }^{6}$ Tengri Babba Kogukond teatab ametlikult kahest institutsionaliseerimise katsest, viimane 15. märtsil 2011, vt http://solyomhang.blogspot.com/ search?updated-min=2011-01-01T00\%3A00\%3A00\%2B01\%3A00\&upd ated-max $=2012-01-01 \mathrm{~T} 00 \% 3 \mathrm{~A} 00 \% 3 \mathrm{~A} 00 \% 2 \mathrm{~B} 01 \% 3 \mathrm{~A} 00 \& \max -$ results $=17$ (22.05.2013). 
Balogh, Sándor 2010. A Szent Korona, Koronázás és a magyar küldetés. 10 July (http://www.szent-korona.hu/korbals.htm - 19.05.2013).

Békés, Márton 2009. Új magyar konzervativizmus. - Konzervatórium, 1 September 2009 (http://konzervatorium.blog.hu/2009/09/01/ uj_magyar_konzervativizmus - 24.04.2013).

Berger, Helen 2010. Are Solitaries the Future of Paganism? A sociologist on the individualized, unlabeled majority of the contemporary Pagan movement. - Patheos, 23 August (http://www.patheos.com/ Resources/Additional-Resources/Solitaries-The-Future-Of-Paganism. html - 26.04.2013).

Berger, Helen; Leach, Evan A.; Shaffer, Leigh S. 2003. Voices from the Pagan Census. A National Survey of Witches and Uuspagans in the United States. Columbia, South Carolina: University of South Carolina Press.

Bobula, Ida 1961. A sumér-magyar rokonság kérdése. Buenos Aires: Editorial Transsylvania.

Boia, Lucian 1999. Történelem és mítosz a román köztudatban. BukarestKolozsvár: Kriterion. [1997. Istorie şi mit în conştiinţa românească. Bucureşti: Humanitas.]

Borangic, Cătălin 2008. Fenomenul dacoman: promotori şi aderenţi. - Buletinul Cercurilor Ştiinţifice Studenţești, Arheologie - Istorie - Muzeologie 14, 119-137.

Campbell, Heidi 2010. When Religion Meets New Media. New York: Routledge.

Cardone, Dino Enrico 2007. Programming the Apocalypse: Recombinant Narrative in Cyberspace. PhD Dissertation Presented to the Faculty of the Graduate School University of Southern California (http:// cdd.linternet.com/multimedia/documenti/CardoneD8287582013_ programming-the-apocalypse_final_10-29-07.pdf, http:// digitallibrary.usc.edu/cdm/ref/collection/p15799coll127/id/589514 $-26.04 .2013)$.

Coco, Angela. Pagan Religiousness as 'Networked Individualism'. Draft conference paper. Spirituality in the 21st Century. $1^{\text {st }}$ Global Conference, Prague, 20-22 March, 2011 (http://www.interdisciplinary.net/critical-issues/ethos/spirituality-in-the-21st-century/ conference-programme-abstracts-and-papers/session-9a-vibrationsindividualism-and-healing/ - 17.05.2013).

Cser, Ferenc; Darai, Lajos 2005. Magyar folytonosság a Kárpát-medencében. Fríg Kiadó.

Czakó, Gábor 2008. Struccok és újpogányok - Régi világrend 13. november (http://www.regivilagrend.eoldal.hu/cikkek/cikkek/czako-gabor_strucc-24.04.2013).

Densuşianu, Nicolae 1913. Dacia preistorică. Bucuresti: Institutul de Arte Grafice Carol Göbl. 
Deuze, Mark 2003. The Web and its Journalisms: Considering the Consequences of Different Types of Newsmedia Online. - New Media and Society 5 (2), 203-230 (doi: 10.1177/1461444803005002004).

Drury, Neville 2009. The Modern Magical Revival. - Lewis, James R.; Pizza, Murphy (toim). Handbook of Contemporary Paganism. Leiden: Koninklijke Brill NV, 13-80 (doi: 10.1163/ej.9789004163737.i-650.7).

Eliade, Mircea 1995. De la Zalmoxis la Genghis-Han. Studii comparative despre religiile şi folclorul Daciei şi Europei Orientale. trad. de Maria şi Cezar Ivănescu, Humanitas: Bucureşti 1995 (põhineb tõlkel De Zalmoxis à Gengis-Khan, Paris 1970).

Fairclough, Norman 2005. Peripheral Vision. Discourse Analysis in Organization Studies: the Case for Critical Realism. - Organization Studies 26 (6), 915-939 (doi: 10.1177/0170840605054610).

Ferlat, Anne 2003. Neopaganism and New Age in Russia. - Folklore. An Electronic Journal of Folklore 23, 40-49 (http://www.folklore.ee/ folklore/vol23/newage.pdf - 24.04.2013).

Frunză, Mihaela 2003. Feminitate şi occultism. - Journal for the Study of Religions and Ideologies 2 (5), 127-142 (www.jsri.ro - 24.04.2013).

Gallacher, Susan 2008. Technology, Ecology and Spirituality: Uuspaganism and Hybrid Ontologies in Technoculture. PhD Dissertation. Murdoch University.

Grieve, Gregory Price 1995. Imagining a Virtual Religious Community: Neo-Pagans and the Internet. Chicago Anthropology Exchange 7, 87-118 (http://libres.uncg.edu/ir/uncg/f/G_Grieve_Imagining_1995. pdf - 25.04.2013).

Götz, László 1989. Keleten kél a Nap. Kulturank a tortenelmi osidokbol. Püski Kiadó.

Hocks, Mary E. 2003. Understanding Visual Rhetoric in Digital Writing Environments. - College Composition and Communication 54 (4), 629-656 (doi: 10.2307/3594188).

Hoffman, Mary; Ford, Debra 2010. Organizational Rhetoric: Situations and Strategies. Thousand Oaks, CA: Sage Publications.

Hubbes, László 2010. 'Signs of Times' - A Semiotic Content-Analysis of Visual Apocalyptic Rhetoric on Hungarian Conspiracist Websites. - Acta Universitatis Sapientiae. Philologica, 176-192 (www.acta. sapientia.ro - 16.05.2013).

INS 2004 = Romania în Cifre [aastaaruanne]. Institutul Naţional de Statistică [Rumeenia Rahvuslik Statistikainstituut], 9.

Ivakhiv, Adrian 2005. Nature and Ethnicity in East European Paganism: An Environmental Ethic of the Religious Right? - The Pomegranate 7 (2), 194-225.

Kincses Nagy, Éva 1991. A turáni gondolat. - Kincses Nagy, Éva (toim). Óstörténet és nemzettudat. 1919-1931. Szeged: JATE Magyar őstörténeti Kutatócsoportja (http://www.tankonyvtar.hu/tortenelem/ ostortenet-nemzettudat-080905-6 - 15.05.2013). 
Kis-Halas, Judit 2005. Újboszorkány-kultuszok a 20. században. A wiccától a cyberboszorkákig. - RUBICONline 14 (7), (http://www.rubicon. hu/magyar/oldalak/ujboszorkany_kultuszok_a_20_szazadban_a_ wiccatol_a_cyberboszorkakig/ - 25.04.2013).

Kiss, Dénes 1999. Bábel elótt - Isten nyelve avagy képességünk a magyar nyelv. Miskolc: Miskolci Bölcsész Egyesület.

Kiszely István 2001. A magyar nép óstörténete. Budapest: Magyar Ház Kiadó. Kovács, Ákos 2004. Árpád-ünnep, Szent Istvánkor, I-II. Mozgó Világ 30, 6-7 (http://epa.oszk.hu/01300/01326/00052/03kovacs.htm - 17.05.2013).

Lichbach, Mark Irving 2001. The Rebel's Dilemma. Michigan: The Michigan University Press.

Lundskow, George 2008. The Sociology of Religion. A Substantive and Trans-disciplinary Approach. Thousand Oaks, CA: Pine Forge Press.

Lupu, Margareta 2007. Tineri fără Dumnezeu. - Monitorul de Sibiu, 26 June (http://www.monitorulsb.ro/cms/site/m_sb/news/tineri_fara dumnezeu_17753.html - 26.04.2013).

Maxwell, Alexander 2004. Contemporary Hungarian Rune-Writing. Ideological Linguistic Nationalism within a Homogenous Nation. Anthropos 99, 161-175 (http://researcharchive.vuw.ac.nz/bitstream/ handle/10063/674/article.pdf?sequence $=3-18.05 .2013$ ).

Mureşan, Radu Petre 2010. Forme ale neopăgânismului în societatea contemporană română. Bucureşti: Facultatea de Teologie. Manuscript.

O'Reilly, Tim 2007. What Is Web 2.0: Design Patterns and Business Models for the Next Generation of Software. - Communication \& Strategies 65 (1), 17-37 (http://mpra.ub.uni-muenchen.de/4580/1/-14.05.2013).

Olteanu, Sorin 2013. Teme Tracomanice (http://soltdm.com/tdman/teme. $\mathrm{htm}-24.04 .2013)$.

Padányi, Viktor 1963. Dentu-Magyaria. Buenos Aires: Editorial Transsylvania.

Pap, Gábor 1999. Hazatalálás. Budapest: Püski Kiadó.

Petre, Zoe 2001. Burebista, contemporanul nostru: Misticele revelatii asupra trecutului si refuzul agressiv al democratiei, 79 (http://www.observatorcultural.ro/Burebista-contemporanulnostru*articleID_1496-articles_details.html - 26.04.2013).

Pike, Sarah M 2001. Earthly Bodies, Magical Selves. Contemporary Pagans and the Search for Community. Berkeley, Los Angeles, London: University of California Press.

Radu, Bogdan Mihai 2010. Young Believers or Secular Citizens? An Exploratory Study of the Influence of Religion on Political Attitudes and Participation in Romanian High-school Students. Journal for the Study of Religions and Ideologies 9 (25), 155-179 (www.jsri.ro 26.04.2013).

Sărbătoare, Octavian 2010. Românul s-a născut zamolxian. Sidney: Sarbatoare Publications. 
Săvescu, Napoleon 2002. Noi nu suntem urmaşii Romei. Bucureşti: Editura Intact (http://www.dacia.org/carte/ - 13.05.2013).

Schnirelman, Victor A 2002. 'Christians! Go home': A Revival of NeoPaganism between the Baltic Sea and Transcaucasia (An Overview). - Journal of Contemporary Religion 17, 2, 197-211. (http:// www.quartetfest.ca/documents/6483/Christians_Go_home.pdf 26.04.2013)

Shirky, Clay 2008. Here Comes Everybody. The Power of Organizing Without Organizations. London: Penguin Books.

Spiridon, Monica 2001. The "Imperial Eyes" and the Borderland Issue. Caietele Echinox, Postcomunism şi Postcolonialism 1 (http://lett. ubbcluj.ro/ echinox/caiete1/23.html - ei ole enam kättesaadav).

Stanciu, Augustin 2005. Dacii neonazişti. - Gazeta de Cluj, 21 November (http://www.hotnews.ro/stiri-presa_regionala_arhiva-1727919-daciineo-nazisti.htm - 20.05.2013).

Strmiska, Michael F. (toim) 2005. Modern Paganism in World Cultures. Comparative Perspectives. Santa Barbara, CA: ABC-CLIO.

Szilágyi, Tamás 2007. Mi az újpogányság? (http://kapu.biz/php/main. php?tart=cikkek\&primary_id=3359 - 13.05.2013).

Szilágyi, Tamás 2008. Sacred Characteristics of the Nation: 'Hungarianism' as Political Religion? Contribution to the REVACERN Young Researchers Exchange Programme (http://www.revacern.eu/ exchange-programme/EP-paper\%20szilagyi.pdf - ei ole enam kättesaadav).

Szilárdi, Réka 2007. A magyarországi neopogány közösségek. - Debreceni Disputa 5 (5), 71-76.

Szốnyi Szilárd 2011. Az ötven legkétesebb magyarországi egyház. - Boldog Özséb Plébánia Blog, 20 February (http://boldogozseb.hu/index. php?option $=$ com_content $\&$ view $=$ article $\& i d=456 \&$ catid $=10 \&$ Item $\mathrm{id}=52-14.05 .2013)$.

Tomiţă, Alexandra 2007. O istorie "glorioasă". Dosarul protocronismului românesc. Bucureşti: Cartea Românească.

Török Péter 2004. Magyarországi vallási kalauz. Budapest: Akadémiai Kiadó.

Vámos-Tóth, Bátor 2010. A név-szerkezetek világfüzére - minden út tamanába vezet. - Tamana világnévtár.

Van Maanen, John; Schein, Edgar 1977. Toward a Theory of Organizational Socialization. Massachusets Institute of Technology. - Working Paper 960 (http://dspace.mit.edu/bitstream/handle/1721.1/1934/SWP-096003581864.pdf?sequence $=1-25.04 .2013$ ).

Varga, Csaba 2005. A Magyar szókincs titka. Fríg Kiadó.

Verdery, Katherine 1994. Compromis şi rezistenţă. Cultura româna sub Ceauşescu, Bucuresti, Editura Humanitas.

Warnick, Barbara 2007. Rhetoric online: Persuasion and Politics on the World Wide Web. New York: Peter Lang Publishing. 


\section{Lisa 1}

Organisatsioonide retoorika aristotellikus raamistikus

\begin{tabular}{|c|c|c|c|c|}
\hline $\begin{array}{l}\text { Aristo- } \\
\text { telese } \\
\text { põhi- } \\
\text { mõtted }\end{array}$ & $\begin{array}{l}\text { Üldised } \\
\text { retoorilised } \\
\text { kategooriad }\end{array}$ & $\begin{array}{l}\text { Tavapärased } \\
\text { vormid }\end{array}$ & \multicolumn{2}{|c|}{$\begin{array}{l}\text { Organisatoorse retoorika } \\
\text { vormid }\end{array}$} \\
\hline \multirow[t]{13}{*}{$\begin{array}{l}\text { Suhtlus- } \\
\text { taktika }\end{array}$} & $\begin{array}{l}\text { Eetos/ } \\
\text { usaldus- } \\
\text { väärsus }\end{array}$ & $\begin{array}{l}\text { Mõistus } \\
\text { Iseloom } \\
\text { Heasoovlikkus }\end{array}$ & \multicolumn{2}{|c|}{$\begin{array}{l}\text { Korporatiivne sotsiaalne } \\
\text { legitiimsus: } \\
\text { kompetents, kogukond }\end{array}$} \\
\hline & \multirow[t]{10}{*}{$\begin{array}{l}\text { Paatos/ } \\
\text { emotsioon }\end{array}$} & \multirow[t]{10}{*}{$\begin{array}{l}\text { Vajadused } \\
\text { Väärtused }\end{array}$} & \multirow[t]{4}{*}{$\begin{array}{l}\text { Väärtuste } \\
\text { edendamine }\end{array}$} & $\begin{array}{l}\text { Otsene } \\
\text { ligitõmbavus }\end{array}$ \\
\hline & & & & $\begin{array}{l}\text { Ühiste } \\
\text { väärtuste } \\
\text { hoidmine }\end{array}$ \\
\hline & & & & Heategevus \\
\hline & & & & $\begin{array}{l}\text { Üksikisikute } \\
\text { kiitmine }\end{array}$ \\
\hline & & & \multirow[t]{5}{*}{ Samastamine } & Samastamine \\
\hline & & & & Vastandus \\
\hline & & & & Ühised huvid \\
\hline & & & & $\begin{array}{l}\text { "Meie" } \\
\text { määratlus }\end{array}$ \\
\hline & & & & $\begin{array}{l}\text { Ühendavad } \\
\text { sümbolid }\end{array}$ \\
\hline & & & \multicolumn{2}{|l|}{ Vajadused } \\
\hline & \multirow[t]{2}{*}{ Logos } & \multirow{2}{*}{$\begin{array}{l}\text { Nõuded, } \\
\text { tõestus, } \\
\text { põhjendus: } \\
\text { induktiivne, } \\
\text { deduktiivne }\end{array}$} & \multicolumn{2}{|c|}{ Nõuded, tõestus, põhjendus } \\
\hline & & & \multicolumn{2}{|c|}{ Organisatoorne entümeem } \\
\hline $\begin{array}{l}\text { Organisat- } \\
\text { sioon }\end{array}$ & $\begin{array}{l}\text { Organisatoor- } \\
\text { sed seadus- } \\
\text { pärasused }\end{array}$ & $\begin{array}{l}\text { Kronoloogiline } \\
\text { Topoloogiline } \\
\text { Ruumiline } \\
\text { Probleemide } \\
\text { lahendamine }\end{array}$ & \multicolumn{2}{|c|}{$\begin{array}{l}\text { Traditsioonilised } \\
\text { organisatoorsed } \\
\text { seaduspärasused, } \\
\text { Väidete visuaalne paigutus } \\
\text { Veebilehel liikumine }\end{array}$} \\
\hline
\end{tabular}




\begin{tabular}{|l|l|l|l|}
\hline Stiil & $\begin{array}{l}\text { Stiil/ } \\
\text { esteetilised } \\
\text { kategooriad }\end{array}$ & $\begin{array}{l}\text { Metafoor } \\
\text { Keelelised } \\
\text { vahendid }\end{array}$ & $\begin{array}{l}\text { Visuaalsed elemendid } \\
\text { Kaubamärgi loomine } \\
\text { Keel või muud valikud } \\
\text { Muusika või muud helid }\end{array}$ \\
\hline Esitlus & $\begin{array}{l}\text { Verbaalsed } \\
\text { ja mitte- } \\
\text { verbaalsed } \\
\text { kombed }\end{array}$ & $\begin{array}{l}\text { Žestid, } \\
\text { liigutused, } \\
\text { häälekvaliteet }\end{array}$ & $\begin{array}{l}\text { Meediavalik: TV, trükitud } \\
\text { materjal, internet, avalikud } \\
\text { kohtumised jne }\end{array}$ \\
\hline Mälu & $\begin{array}{l}\text { Meeles- } \\
\text { pidamine }\end{array}$ & Mälunipid & $\begin{array}{l}\text { Pole organisatoorses } \\
\text { retoorikas oluline }\end{array}$ \\
\hline
\end{tabular}

Allikas: Hoffman, Ford 2010: 49.

Märkus: esiletõstetud elemente on selles uurimuses kasutatud Rumeenia ja Ungari etnopaganlike organisatsioonide veebiretoorika esitluse hindamiseks.

\section{Lisa 2}

Ungari ja Rumeenia etnopaganlike organisatsioonide võrdlev tabel

\begin{tabular}{|l|l|l|}
\hline Põhiomadused & Ungarlased & Rumeenlased \\
\hline $\begin{array}{l}\text { Ideoloogiate } \\
\text { päritolu, } \\
\text { v.a New Age }\end{array}$ & $\begin{array}{l}\text { "Ugri-türgi sõda", } \\
\text { sõdadevaheline turanism, } \\
\text { noole ja risti (Arrow-cross) } \\
\text { partei, läänepoolse eksiili } \\
\text { diasporaa, rokkooper } \\
\text { "István Király", Siberi ja } \\
\text { Kesk-Aasia etnograafia, } \\
\text { traditsionalism, Tan } \\
\text { Kapuja budistlik kolledž } \\
\text { Budapestis. }\end{array}$ & $\begin{array}{l}\text { Kaheline Raudkaart, } \\
\text { riigi toetatud ametlik } \\
\text { protokronism } \\
\text { 1970. aastatel, Cenaclul } \\
\text { Flacara!; Jooga- } \\
\text { valgustuse liikumised } \\
\text { (MISA), metafüüsiline } \\
\text { traditsionalism }\end{array}$ \\
\hline $\begin{array}{l}\text { Ajaloolised } \\
\text { ideed }\end{array}$ & $\begin{array}{l}\text { Hunni-sküüdi-türgi } \\
\text { vanem koolkond, } \\
\text { Sumeri - Partia uuem } \\
\text { koolkond, }\end{array}$ & $\begin{array}{l}\text { Daakia-Rumeenia } \\
\text { järjepidevuse vanem } \\
\text { Koolkond } \\
\text { Karpaatide monogeneesi } \\
\text { koolkond }\end{array}$ \\
& $\begin{array}{l}\text { Daakia - traakia - } \\
\text { pelasgi vanem koolkond, } \\
\text { Karpaatia-Doonau uuem } \\
\text { koolkond }\end{array}$ \\
\hline
\end{tabular}




\begin{tabular}{|c|c|c|}
\hline $\begin{array}{l}\text { Ideed } \\
\text { geograafilisest } \\
\text { ülimus- } \\
\text { likkusest }\end{array}$ & $\begin{array}{l}\text { Karpaatia ja Doonau } \\
\text { ala kui püha keskus - } \\
\text { päritolu paik (neoliitilised } \\
\text { kirjutised jne.), "pan- } \\
\text { ungarlus", Tamana! }\end{array}$ & $\begin{array}{l}\text { Karpaatia ja Doonau } \\
\text { ala kui püha keskus } \\
\text { - päritolu paik } \\
\text { (neoliitilised kirjutised } \\
\text { jne.),"pan-pelasgiaanlus", } \\
\text { antroponüümia, } \\
\text { toponüümia }\end{array}$ \\
\hline $\begin{array}{l}\text { Religioossed } \\
\text { ideed }\end{array}$ & $\begin{array}{l}\text { Erinevad šamanistlikud } \\
\text { traditsioonid } \\
\text { (Siberi, Kesk-Aasia), } \\
\text { zoroastrism / manihheism, } \\
\text { Kristuse-eelne kristlus, } \\
\text { vastandav ja integreeriv } \\
\text { suhtumine ajalooliste } \\
\text { kirikute suhtes: Katoliku } \\
\text { (paulisti mungad); } \\
\text { kalvinistlik (noored } \\
\text { pastorid) }\end{array}$ & $\begin{array}{l}\text { Zalmoxianism, } \\
\text { hüperboreanism, } \\
\text { jumalanna-religioon } \\
\text { Kristuse-eelne kristlus, } \\
\text { ei ole liigselt tõrjuv } \\
\text { õigeusu suhtes, vanemad } \\
\text { suundumused integreerida } \\
\text { õigeusku vaimsust } \\
\text { (sõdadevaheline aeg, } \\
\text { kommunismijärgne } \\
\text { periood), idamaine } \\
\text { okultism }\end{array}$ \\
\hline $\begin{array}{l}\text { Koht uus- } \\
\text { paganluses / } \\
\text { new age }\end{array}$ & $\begin{array}{l}\text { Eristub šamanistliku } \\
\text { orientatsiooni poolest, } \\
\text { iseseisev uus religioon } \\
\text { Rikkalik mütoloogia } \\
\text { / mütopoeesia } \\
\text { (Arvisura, Yotengrit), } \\
\text { apokalüptitsism (Nyirka } \\
\text { ettekuulutus) - kerge } \\
\text { proselütism }\end{array}$ & $\begin{array}{l}\text { Eristub müstikakultusega } \\
\text { (varjatud) apokalüptitsism } \\
\text { Vähem rikkalik } \\
\text { mütoloogia, } \\
\text { üsna ülepakutud } \\
\text { spekulatsioonid } \\
\text { historiograafilistest } \\
\text { ürikutest, puuduv või } \\
\text { vähene proselütism }\end{array}$ \\
\hline $\begin{array}{l}\text { Religioossuse } \\
\text { tase }\end{array}$ & $\begin{array}{l}\text { Pigem linlik šamanism } \\
\text { või moondatud kristlus, } \\
\text { koos või ilma vulgaarse } \\
\text { šovinismita, elavad } \\
\text { Kesk-Aasia rituaalid, } \\
\text { šamanistlikud ekstaasid }\end{array}$ & $\begin{array}{l}\text { Pikem okultistlik } \\
\text { müstitsism ja/või } \\
\text { vulgaarne šovinism, } \\
\text { taaselustatud } \\
\text { kombetalitlused, jooga }\end{array}$ \\
\hline Ksenofoobia & Jah + antisemitism & Jah + antisemitism \\
\hline $\begin{array}{l}\text { Vandenõu- } \\
\text { teooria }\end{array}$ & Jah & Jah \\
\hline $\begin{array}{l}\text { Organi- } \\
\text { satoorne taust }\end{array}$ & $\begin{array}{l}\text { Kirikud, } \\
\text { võitluskunstikoolid } \\
\text { (Baranta), riigi- ja } \\
\text { rahvusvahelised pühad, } \\
\text { kirjastused, teaduslikud } \\
\text { organisatsioonid ja } \\
\text { väljaanded }\end{array}$ & $\begin{array}{l}\text { Rahvuspühad, } \\
\text { kirjastused, teaduslikud } \\
\text { organisatsioonid ja } \\
\text { väljaanded, dakoloogia } \\
\text { konverentsid }\end{array}$ \\
\hline
\end{tabular}




\begin{tabular}{|l|l|l|}
\hline Veebitegevus & $\begin{array}{l}\text { Veebilehed, blogid, } \\
\text { foorumid }\end{array}$ & $\begin{array}{l}\text { Veebilehed, blogid, } \\
\text { foorumid }\end{array}$ \\
\hline $\begin{array}{l}\text { Karis- } \\
\text { maatilised } \\
\text { juhid }\end{array}$ & $\begin{array}{l}\text { Pap Gábor, (Varga Csaba) } \\
\text { Grandpierre Attila, } \\
\text { Kovács-Magyar András, } \\
\text { Heffner Attila, Máté Imre, } \\
\text { (p. Árva Vince), Földvári } \\
\text { Tamás, Sólyomfi Nagy } \\
\text { Zoltán, Mireisz László, } \\
\text { Nukics Ferenc... } \\
\text { Napoleon Săvescu, Pavel } \\
\text { Coruț, Artur Silvestri, } \\
\text { Dan Lupu, (Gregorian } \\
\text { Bivolaru) +pseudonüümid }\end{array}$ \\
\hline $\begin{array}{l}\text { foorumites) } \\
\text { vanuse- }\end{array}$ & \\
\hline vahemik & $\begin{array}{l}\text { Enamasti noored, } \\
\text { moned 40-50aastased + } \\
\text { vanemaealised pagulased }\end{array}$ & $\begin{array}{l}\text { Noored ja 40-50aastased } \\
\text { +vanemaealised } \\
\text { pagulased }\end{array}$ \\
\hline
\end{tabular}

\section{Summary}

\section{Religious Minorities' Web Rhetoric: Romanian and Hungarian Ethno-Pagan Organizations}

Keywords: Romanian and Hungarian Ethno-pagans, web rhetoric, religious minorities

The comparative study of Romanian and Hungarian Neopagan organizations with an ethnocentric or "Ethno-pagan" ideology is an exploratory research aimed at mapping the similarities and the differences between these religious minorities, with a highlight on their level of institutionalization, their core values and degree of political mobilization. Zalmoxian groups and organizations promote the revival of Romanian spirituality through a process of reconnection to its ancient, supposedly Dacian and Thracian roots; by the same token, Hungarian Shamanist movements are aimed at recovering a supposedly lost spirituality, built-in into the deepest layers of Hungarian language and cultural practices. A web rhetoric analysis of these organizations is carried out in order to assess audience involvement, communication style and the use of multimedia tools to convey their messages. 


\section{MAAILM ja \\ MULTITASKING}

\section{Koostanud ja toimetanud MARE KÕIVA}

http://www.folklore.ee/rl/pubte/ee/cf/multi

ISBN 978-9949-544-01-1

Tartu 2014

Trükis ilmunud:

MAAILM ja MULTITASKING. Tänapäeva folkloorist 10.

Tartu 2014

Sarja peatoimetaja: Eda Kalmre

Kogumiku koostaja ja toimetaja: Mare Kõiva

Keeletoimetaja: Asta Niinemets

Kaanekujundus: Lilli-Krõõt Repnau

Küljendus: Diana Kahre

HTML: Diana Kahre

Trükist toetasid: teadusteema SF 0030181s08, ETF grant nr 8137 ja IUT22-5 ning Eesti Kultuurkapital.

E-raamatu valmimist toetas: EKKM14-344 Eesti keele, kultuuri ja folkloori kasutusalade laiendamine ja tutvustamine elektroonilistel infokandjatel.
(C) Mare Kõiva
(C) autorid
(C) EKM Teaduskirjastus 2014 